IV. On the Lepidoptera of the Amazons, collected by Dr. James W. H. Trail, during the years 1873 to 1875. By Arthur Gardiner Butler, F.L.S., F.Z.S., \&c.

[Read February 5th, 1879.]

\title{
Part III.-NOCTUITES.
}

Dr. Trail obtained 149 species of Noctuites during his expedition up the Amazons, but four of these were not in a sufficiently perfect condition for identification; so that the number may be reckoned as 145, of these species no less than 55 are forms new to science.

Owing to the recklessness with which some authors have characterized genera in this tribe, I have been saved the necessity of describing any; but, at the same time, this recklessness has caused so much confusion in the identification and location of species, that hardly a genus of the New World Noctuites exists which does not need more or less revision.

\section{Family BOMBYCOID A.}

Microcelia, Guénée.

1. Microcælia discincta, n. sp.

Primaries above whity-brown, feebly mottled with clay colour; external fourth, excepting at apex, chocolatebrown, crossed internally by an ill-defined series of small tawny spots, and limited by a brown-edged transverse whitish discal line; discoidal spots ill-defined, greyish with pale margins; a tapering subbasal streak, an oblique dash near the centre of the costal area and a cuneiform costal spot beyond the cell chocolate-brown; two parallel bisinuated brown lines from the cell to the inner margin; a marginal series of whitish-edged black dots; fringe pale brown, spotted with dark brown; secondaries sericeous smoky-brown, paler towards the base; fringe whitish, traversed by an ill-defined brown line; head and thorax

TRANS. ENT. SOC. 1879.-PART I. (APR.) C 2 
white; collar reddish; abdomen whity-brown; primaries below greyish-brown, with a pink gloss, borders whitybrown, speckled with darker brown; costal border towards apex red-brown, with four whitish costal dots; secondaries whitish, speckled with brown and with a pinky-brown diffused discal band; marginal line of all the wings black and undulated; body whitish: expanse of wings 1 inch 3 lines.

Rio Trombetas, near the Falls, 28th February, 1874.

\section{Family, LEUCANIID A.}

\section{Leucania, Ochsenheimer.}

2. Leucania antica.

Leucania antica, Walker, Lep. Het. ix. p. 100, n. 52 (1856).

Curimatá, Rio Juruá, 30th October ; Pupunha, 4th to 6th November, 1874.

3. Leucania dorsalis, var.

Leucania dorsalis, Walker, Lep. Het. ix. p. 98, n. 43 (1856).

Aveyros, Rio Tapajos, 11th March, 1874.

\section{Family GLOTTULID A.}

Giscala, Walker.

4. Giscala quadricolor.

Giscala quadricolor, Walker, Lep. Het. xv. p. 1672, n. 1 (1858).

Ceroctena pictipennis, Felder, Reise der Nov. Lep. iv. pl. cxix. fig. 3 (1874).

Rio Javary, 3rd December, 1874.

\section{Family XYLOPHASIIDA.}

\section{Prometopus, Guénée.}

M. Guénée says of this genus: "Il faudrait connaître de ce genre curieux pour lui assigner une place définitive. L'insecte parfait offire une assez grande analogie avec les 
Diphtera, dont il différe, du reste, beaucoup par son organisation, ainsi qu'on pourra s'en convaincre par les caractères ci-dessus. Peut-être devra-t-il se placer dans les Notodontides, quoiqu'il ait bien l'aspect d'une Noctuelle."

Walker adds: "This genus resembles some of the Notodontida, and, like some others, may be removed from the Hypogrammida, but does not well agree with the characters of any other family of Noctuites."

After reading the above, I find it very difficult to point out characters by which Prometopus may readily be distinguished from Xylophasia, but the discocellulars do seem to be rather less angulated.

\section{Prometopus assuetus, n. sp.}

Extremely like Xylophasia sodalis, from Japan. Primaries whity-brown, clouded with greyish-brown and with black markings, much as in $X$. rurea, but more defined, a large additional subapical black spot near the costa; secondaries sericeous cupreous-brown, brightest and darkest on external area; costal margin white; fringe whitish, spotted with purplish-brown; body whity-brown; collar and tegulæ rosy-greyish, traversed by arched black lines; undersurface coloured much as in X. hepatica, but even darker in colour, the blackish discal line still more irregular; body whitish: expanse of wings 1 inch 6 lines.

Boa Vista, Rio Purus, 12th September; Pupunhazinho, Rio Juruá, 8th November, 1874; Rio Jutahi, 20th January, 1875.

6. Prometopus ordinarius, n. sp.

Most like Xylophasia verbascoides, but, in marking, still more like the species of Lithophane; primaries purplish-brown; the veins, a number of longitudinal lines between the veins, a number of oblique costal dashes, a subcostal and an internal longitudinal streak, black, with pale borders; female, with two whitish lines on the disc, towards apex; secondaries pearly-white, becoming brownish towards costal and abdominal borders; outer border broadly dark brown, with cupreous lustre; fringe whitish, varied with brown; body pale red-brown; collar purplishslate colour, traversed by pale lines; tegulæ purplish, with black submarginal dotted line and reddish fringe; undersurface almost as in the preceding species, exhibit- 
ing the normal coloration and pattern of Xylophasia: expanse of wings 1 inch $3-8$ lines.

Curimata, Rio Juruá, 30th October; near mouth of Rio Juruá, 14th November; near Santa Cruz, Rio Solimões, 9th December, 1874; Boaventura, Rio Jutahi, 24th January, 1875.

\section{Prodenia, Guénée.}

7. Prodenia inquieta.

Xylina inquieta, Walker, Lep. Het. xi. p. 632, n. 22 (1857).

Prodenia strigifera, Walker, Lep. Het. xv. p. 1678 (1858).

Juruana, Rio Purus, 24th September; Curimata, Rio Juruá, 30th October; Barreiras das Araras, Rio Solimões, 15th November; Rio Javary, 3rd December, 1874.

Allied to "Laphygma" orbicularis ; also very close to Prodenia ignobilis of Jamaica, but differing in the colour of its legs.

\section{DARGIDA, Walker.}

8. Dargida singularis, n. sp.

Primaries above fuliginous-brown, with a faint lilacine gloss ; the margins of the discoidal spots a falciform line below the cell, an oblique line angulated near the costa, some dashes upon the apical third of costa, an oblique apical line and the last branch of the subcostal vein pale tawny (cupreous when viewed from the side); the ordinary spots, and a discal series of irregularly-placed, tawnyedged discal spots, blackish; a transverse pale yellowish line across the end of the cell; a submarginal series of dots, and an interrupted marginal line, black; a marginal series of white points, beyond which the fringe is crossed by ferruginous dashes; secondaries white, with broad costal and external blackish borders; body dark brown, varied with whity-brown and blackish; wings below much paler, the costal borders tinted with pink; discocellular spots blackish; an arched postmedian stripe on both wings, ill-defined and interrupted upon the secondaries; primaries with the discoidal area greyish; an irregular whitish discal line; secondaries white, the costal area pinky-brown; a costal dash near the base; an apical 
dusky patch; fringe brown; body whity-brown, slightly tinted with pink: expanse of wings 1 inch 4 lines.

Villa Nova de Parentins, 5th April, 1874.

The pattern of the primaries in this species is quite like that of "Heliophobus" dissectus, Walker, from Ceylon, to which it is evidently nearly allied. The two genera can at once be distinguished by the antennæ, which in Daryida are simple in both sexes; the latter genus should perhaps be placed near to Dianthacia.*

It is just possible that Sepp's $P$. phytolacca may be $D$. singularis, but his figure is by far too rough to enable me to form any decided opinion respecting it.

\section{Family APAMIID E.}

\section{Celmen, Stephens.}

\section{Celæna fuscata, n. sp.}

Primaries above fuliginous-brown, sericeous; costal border crossed by șhort blackish dashes; a very irregularly zigzag black line crossing the wing at basal third, limiting the central band internally, the latter slightly darker than the ground-colour, enclosing the reniform spot, which is white, edged with black, and with a testaceous or white outer margin; a blackish streak from the reniform spot to the inner margin; outer margin of the central band sinuous and black, not crenulated or dentated; a dusky discal line parallel to, and just beyond, the central band, and a submarginal line also parallel to it; secondaries white, pure in the male and sordid in the female, with greyish apical border, and narrow interrupted blackish marginal line; thorax fuliginous-brown, abdomen greyishbrown; wings below altogether paler; primaries greyish, the internal area, reniform spot, inferior border of discal and submarginal lines, white; the discal and submarginal lines alone visible, most distinct towards the costa; a marginal series of triangular black dots; secondaries white, the costal area sprinkled with brown scales, and crossed beyond the middle by an ill-defined arched line; a black discocellular dot; body whity-brown: expanse of wings 11 to $12 \frac{1}{2}$ lines.

†. Sapucaia Oroca, Rio Madeira, 15th May; \& Mara-

* “Dianthacia” graminicoleus is a Dargida. 
patá, Rio Negro, 29th December, 1874; \& Rio Jutahi, 25th January, 1875.

10. Celæna dentilineata, n. sp.

Coloration of the preceding, but the line across the basal third of primaries very indistinct, the line limiting the central band externally distinctly denticulate-sinuate; the upper half of the reniform spot, and sometimes the whole of it, testaceous or dull red; the line beyond the central band very indistinct; the fringe much longer; secondaries darker, frequently suffused with greyish, with the whole outer border greyish-brown; fringe white or whitish and longer; primaries below sericeous grey with grey-speckled whitish costal and external borders and reniform spot; a dusky costal crescent beyond the middle; a marginal series of black dots; secondaries sordid white with grey-speckled costal and external borders, apical half of fringe streaked and speckled with grey; a minute dusky discocellular dot and abbreviated discal line; body white: venter with three or four central blackish dots: expanse of wings 11 to $13 \frac{1}{2}$ lines.

Rio Madeira, 18th May; Itatoro, Rio Madeira, 2nd June; Vista linda, Rio Purus, 8th October; Tanariá, 9th October; Parieatuba, 10th October; Rio Juruá, 7th November; San Antonio, Rio Javary, 16th December, 1874.

Allied to C. tepens.

\section{Perigea, Guénée.}

11. Perigea otiosa.

Perigea otiosa, Walker, Lep. Het. xv. p. 1693 (1858).

Fazenda, near the Rapids, Rio Tapajos, 14th March, 1874.

var. $P$. paupera, Walker, l. c.

Rio Madeira, 14th and 27th May; Manaos, 26th and 29th August; Fonteboa, Rio Solimões, 17th November; Rio Javary, 3rd December, 1874.

var. ? P. imbella, Walker, p. 1692.

Sapucaia oroca, Rio Madeira, 15th May, 1874.

If the latter be a modification of the preceding, it will take priority. 
12. Perigea hylea.

Phalena-Noctua Hylea, Cramer, Pap. Exot. iv. p. 48 ; pl. 312 , fig. E (1782).

of Cararaucu, 16th April; \& Manaos, 6th November, $17 t$.

This species is new to the Collection of the British Museum.

\section{Condica, Walker.}

13. Condica cupentia.

Phalcena cupentia, Cramer, Pap. Exot. iii. p. 103; pl. 252, fig. E (1782).

Condica palpalis, Walker, Lep. Het. ix. p. 240, n. 1 (1856).

Rio Juruá, near the mouth, 14th November; Barreiras de Tunantins, 12th December, 1874.

Family NOCTUID A.

Agrotis, Ochsenheimer.

14. Agrotis repleta.

Agrotis repleta, Walker, Lep. Het. xi. p. 736 (1857).

Rio Purus, 9th September, 1874.

The type of this species is from Mexico.

Family HADENID A.

Hadena, Guénée.

15. Hadena aduncula.

Hadena aduncula, Felder, Reise der Nov. Lep. iv. pl. 110, fig. 4 .

Hadena aperiens (part), Walker, Lep. Het. xi. p. 755 (1857).

Rio Jutahi, 18th, 21st and 23rd January, 1875.

One example from Venezuela was with the examples of H. aperiens, it differs from Amazonian specimens only in being slightly larger. 
Family XYLINID A.

Magusa, Walker.

16. Magusa strigifera.

Magusa strigifera, Walker, Lep. Het. xi. p. 762 (1857).

Rio Juruá, 6th November; Rio Solimões, 9th December, 1874 .

The type from St. Domingo is rather faded.

17. Magusa dissidens.

Magusa dissidens, Felder, Reise der Nov. Lep. iv. pl. 108, fig. 50 .

Near Santa Cruz, Rio Solimões, 9th December, 1874; Coary, 11th January, 1875.

Allied to $M$. orbifera (Xylina orbifera, Walker).

\section{Nystalea, Guénée.}

18. Nystalea squamosa, n. sp.

Allied to $N$. superciliosa, much smaller, the primaries less produced at apex; primaries fuliginous-brown, with darker discal hastate spots between the veins; costal border beyond the middle crossed by oblique black dashes; basal two-thirds, particularly near the internal border, and the spots on external area, sprinkled with lilac scales; a central trisinuate black-edged red-brown stripe from the costa to the first median branch; reniform spot pale, black-edged, white-bordered, bisinuated in front; two slightly sinuous oblique blackish lines just beyond the cell; a submarginal series of dusky spots, black near external angle; a marginal series of black dots; secondaries white, with broad dark-brown border as in N. superciliosa; body dark brown, thorax sprinkled with lilacine scales, abdomen with pale hind-borders to the segments; primaries below sericeous fuliginous-brown, with paler costal and internal borders; secondaries white, with testaceous costal border and brown external border; body whity-brown, first and second pairs of legs fuliginousbrown above: expanse of wings 2 inchẹ 1 line.

Rio Sapó, 12th December, 1874.

The genus Nystalea seems to me to be quite as closely allied to Notodonta as to Cucullia, and I think its Noctuid character very doubtful; the neuration does not help to 
solve the difficulty, as in this respect there is no more than a generic difference between Notodonta and Cucullia, and not that between Cucullia and Nystalea. In Cucullia the antennæ are simple in both sexes but thickening gradually towards the base; in Nystalea they are of the same form, but are pectinated from the base to about the middle, where the pectinations fade away imperceptibly; in Notodonta they are much more strongly pectinated nearly to the apex. With regard to the pupa the Cucullia type seems to be more Bombycidian than that of Notodonta; this is also the case with Calophasia: all of these genera have the discoidal cell of primaries below clothed with long hair scales. The long bodies, with their terminal tufts and hood-like collars, and the wings with their streaky markings in various shades of brown forcibly recall to one's mind such Notodontid genera as Etobesa, Destolmia, Danima and even Pheosia. Is Cucullia a Noctuid genus? and if so-why?

\section{Family H EMEROSIID E.}

Aphusia, Walker.

19. Aphusia marmorea, n. sp.

Basal half white, external half stramineous, irrorated with ferruginous; a blackish band beginning at centre of inner margin, abruptly enlarged to double its width just below the third median branch and then narrowing towards the costa; an arched ferruginous band uniting with the centre of the blackish band, whence it runs, slightly obliquely, almost to the outer margin, interrupted just below the last subcostal branch by a longitudinal white streak and then running inwards to the costal margin; base blackish; a ferruginous spot near the base of inner margin; secondaries sericeous brown, darkest at apex; apical half of fringe black, interrupted by silver-grey dots at the ends of the veins, anal half silver-grey; head and thorax stramineous, speckled with ferruginous; abdomen brown; undersurface sericeous leaden-grey; palpi and costal margin of primaries yellowish; inner border of primaries white: expanse of wings $11 \frac{1}{2}$ lines.

Rio Jutahi, 31st January, 1875.

Allied to "Agrophila" rudisana and A. transmutata, which (with the other New World species referred to Agrophila by Mr. Walker) may be transferred to Aphusia. 


\section{Family ANTHOPHILID R.}

\section{Xanthoptera, Guénée.}

20. Xanthoptera botyoides.

Xanthoptera botyoides, Guénée, Noct. ii. p. 240, 1024 (1852).

Pupunha, Rio Juruá, 1st November; Rio Solimões, 19th December, 1874.

I found several examples of this species in a supplementary drawer with a MS. label in Mr. Walker's handwriting, bearing the name "Xanthodes aneocincta;" no description of the species occurs under this name in the Museum Catalogue.

\section{Microphysa, Guénée.}

21. Microphysa fumosa, n. sp.

Primaries smoky-brown, crossed near the base by an angular black line; a whitish-edged irregular black line just beyond the middle; a blackish dot at the inferior angle of the discoidal cell; a marginal series of fusiform black dots; a slender irregular oblique discal line from the costa; secondaries pale grey; fringe of all the wings smoky-brown with blackish basal markings; head and thorax blackish, abdomen greyish-brown; posterior legs above whitish; primaries below slaty-grey; costal border brown; fringe spotted with brown; marginal black dots as above; secondaries sordid white, with marginal black dots; discocellulars and an ill-defined discal line dusky; fringe brown, spotted with blackish; body below pale brown: expanse of wings $7 \frac{1}{2}$ lines.

Rio Jutahi, 5th February, 1875.

The smallest true Microphysa known to me.

Family PALINDIID AE.

Eulepidotis, Hübner.

22. Eulepidotis ilyrias.

Phalena ilyrias, Cramer, Pap. Exot. i. p. 15, pl. 10, fig. E (1779).

Rio Jutahi, 27 th January; Barreira branca, Rio Jutahi, 3rd February; Santarem, 4th February, 1875. 
23. Eulepidotis mabis.

Palindia mabis, Guénée, Noct. ii. pp. 277, 1077 (1852).

Palindia fumata, Felder, Reise der Nov. Lep. iv. pl. 91 , fig. 17 .

Manaos, 13th June; Rio Juruá, 3rd November, 1874.

\section{Section Palindia, Guénée.}

24. Eulepidotis thecloides.

Palindia thecloides, Walker, Lep. Het. xii. p. 851, n. 16 (1857).

West bank of Rio Madeira, about $5^{\circ} 30^{\prime}$ S., 16th May; also 18th and 22nd May; Curimata, Rio Juruá, 30th October; Rio Juruá, 2nd and 3rd November; Tabatinga, 27th November, 1874; Rio Jutahi, 30th and 31st January; Barreira branca, Rio Jutahi, 3rd February, 1875 .

25. Eulepidotis julianata.

Phalcena julianata, Stoll, Suppl. Cramer, p. 40, pl. 8 , fig. 4 .

Palindia egala, Walker, Lep. Het. Suppl. iii. p. 807 (1865).

Rio Madeira, West bank, 16th and 18th May; Ilha das Araras, 3rd June; Rio Negro, 4th July; Juruapuca, Rio Juruá, 28th and 29th October; Curimata, 30th and 31st October; Rio Juruá, 13th November, 1874; Boaventura, Rio Jutahi, 14th January; Rio Jutahi, 21st January; above Curuem, 29th January, 1875.

26. Eulepidotis spectabilis.*

Palindia spectabilis, Walker, Lep. Het. xv. p. 1767 (1858).

Fazenda, near the Rapids, Rio Tapajos, 4th May, 1874.

Allied to E. guttata and albata of Felder. A rare species, not previously in the Collection of the British Museum.

27. Eulepidotis argyritis, n. sp.

Nearly allied to $\boldsymbol{E}$. dominicata, but rather larger, the silvery area at the base of primaries larger; the central belt concave internally, expanded upon the costal margin,

* Possibly this may be Palindia perlata of Guenée. 
angularly excised in front; the silver patch beyond it of little more than half the size; the disc brightly shot with purple; the discal bands blacker, the inner one much more arched, the outer one very wide in the centre, with well-marked pale external border; markings of secondaries darker, the patch above the caudal angle smaller; undersurface altogether brighter in colour: expanse of wings 1 inch 10 lines.

Rio Jutahi, 27th January, 1875.

28. Eulepidotis alabastraria.

Noctua alabastraria, Hübner, Exot. Schmett. Zutr. figs. 311, 312 .

Palindia testaceiceps, Felder, Reise der Nov. Lep. iv. pl. 111, fig. 16 .

Rio Tapajos, 12th March, 1874.

\section{Phrygionis, Hübner.}

29. Phrygionis corinna.

Phalana (Noctua) corinna, Cramer, Pap. Exot. i. p. 47, pl. 29, fig. H (1779).

Palindia crocoptera, Felder, Reise der Nov. Lep. iv. pl. 111, fig. 18.

Forest near Serra de Juruty, 31st March, 1874.

30. Phrygionis dives, n. sp.

Primaries above clay-coloured, tinted with violet, with the base and costal border bright ochreous; a short black line, edged externally with metallic bluish-green across the costal border near the base; an internally black-edged green line crossing the wing at basal fourth, and followed by a grey line; a second very oblique grey line, followed by a metallic green line near the middle of the wing; discocellulars grey; three divergent grey lines across the disc, the central one with green internal border; an externally black-edged silver submarginal line; two or three grey marginal dots near the apex; fringe whity-brown traversed by three parallel slender brown lines; secondaries ochraceous, imperceptibly shading into stramineous towards the base and costa, and into clay-colour upon the median interspaces, across the centre of these interspaces there is a bifid greyish-bordered opaline spot; a partially black and white-edged marginal orange spot on second median interspace; margin pale, white near anal angle, externally 
edged with blackish-brown; fringe whity-brown, with a dark basal line; abdominal fringes whitish; body ochraceous, the thorax orange in front, the collar crossed by a pearly line; abdomen paler, with the base and sides whitish; wings below pale ochreous, primaries darker towards costa and apex; a red-brown bar across the end of the cell and a subapical nebula of the same colour; centre of costal border dull brown; fringe pale and greyish; secondaries with a brownish spot at centre of costa; outer margin white, diffused, with brown external marginal line; fringe testaceous; palpi ochreous; legs white below, anterior pair with the femora above brown, and the tibiæ and tarsi ochreous; second pair above ochreous, brightest at base of tibiæ and on the knees, where there is a small external opaline-white tuft; posterior pair white above, the tibiæ very robust and terminating in a tuft of hairs, black internally and opaline externally; pectus white; venter pale creamy-ochraceous: expanse of wings 1 inch 2 lines.

On board the Yeamiaba, 12th August; Rio Juruá, 7th November, 1874.

This beautiful species, although it has the general appearance of $P$. corinna, ${ }^{*}$ is more nearly allied to $P$. caruleilinea of Walker: a brown species, with somewhat similar markings.

31. Phrygionis setosa, n. sp.

Primaries above dark clay-coloured, glossed with rosy lilacine; the costal border and apex ochreous, spotted with metallic blue and black; an irregularly-arched band (almost like the letter $\mathbf{D}$, but with the lower part cut off) from basal third to near the outer margin, orange with metallic blue exterior margin, its interior margin bounded in part by a sinuated slender blackish line; within the arched band is a singular maculated black-edged marking like a falciform hook; two subapical longitudinal plumbageous streaks; a finely black-edged submarginal silver line; outer border orange; fringe grey; secondaries creamy testaceous, becoming rosy-brown near the outer border and on the median interspaces; outer border orange, bounded within by a partly black-edged silver line, which separates into a distinct spot upon the first

* A species occurring at Pará has been confounded by Walker with P. corinna: it differs in having the metallic bands bright blue and the area between the first and second bands purplish-brown; the external area also is darker; the central blue line strongly angulated. I propose for this species the name of $P$. regalis. 
median interspace, and is surmounted by a second similar spot tinted with blue; fringe grey, excepting at anal angle and upon abdominal border, where it is white; some scattered erect black bristles upon the inner margin of the abdominal fold; head and thorax orange; abdomen sordid flesh-pink, whitish at the sides and with the centre of the two basal segments orange; undersurface sericeous, primaries brown, with whitish internal area; secondaries whitish, with brownish costal border; body whitish: expanse of wings 1 inch.

Rio Tapajos, 12th March; West bank of Rio Madeira, 15th and 16th May; Ilha das Araras, 3rd June; on board the Yeamiaba, 11th August; Rio Juruá, 4 40' S., $66^{\circ} 40^{\prime}$ W., 29th October; 6th November; Rio Javary, 5th December, 1874; Boaventura, Rio Jutahi, 26th January; Boa Vista, 1st February; Barreira branca, 3rd February; Santarem, 4th February, 1875.

This and the following species have the metallic lines arranged much as in the Geometrid species Palyas aura.

\section{Phrygionis metalligera, n. sp.}

Primaries pale buff, apical and costal areas faintly opaline; centre of internal area shot with rose colour, the dark spots upon it shot with blue; basal area and costa speckled with dark brown and silver; an irregularly $\Omega$-shaped silver line, from inner margin to subcostal vein, slenderly black-edged externally, and partially bordered with cupreous internally, enclosing an oblong internomedian black-brown patch and several small spots of the same colour; a curved discal series of five or six black dots, beyond which is a second abbreviated series of three smaller dots near external angle; a semicircular silver line limiting the apical area, internally bordered with cupreous ; a submarginal series of black dots, each pair of which is united by a little silver line; two subapical longitudinal silver dashes, the lower one dividing an apical black spot; fringe at apex spotted with black; secondaries much paler, nearly white, with darker buff fringe and margin; a submarginal series of black dots and silver connecting lines as in the primaries; a reddish spot near the anal angle partly enclosed by two black-dotted silver spots, surmounted by a buff and then a silver spot; head and thorax pale buff, the latter dotted with brown; abdomen greyish, whitish at the sides and base, a central subbasal red-brown spot; undersurface creamy-white, 
glistening; wings with a few minute marginal black dots at the ends of the veins, connected on the primaries by a slender undulated marginal brown line; fringe spotted with greyish: expanse of wings $10 \frac{1}{2}$ lines.

On board the Yeamiaba, 11th August, 1874.

\section{Dyops, Guénée.}

33. Dyops ocellata.

Phalcena (Noctua) ocellata, Cramer, Pap. Exot. iii. pl. 276, fig. E (1782).

On board the Yeamiaba, 29th March; Abacaxis village, 12th May, 1874; Rio Solimões, 8th January; Manaos, 11th February, 1875.

This very beautiful bronze-tinted species is certainly not congeneric with $D$. hatuey and $D$. confligens, the latter are long-winged insects, with short and thick palpi.

\section{Family PLUSIID A.}

Plusia, Ochsenheimer.

34. Plusia includens.

Plusia includens, Walker, Lep. Het. xii. p. 914, n. 59 (1857).

Rio Madeira, East bank, $5^{\circ} 50^{\prime}$ S., 18th and 23rd May, 1874.

Since mistakes are best corrected as soon as discovered, I may here observe that Walker's P. invicta, from Borneo, is a Limacodid of the genus Phrixolepia.

\section{Basilodes, Guénée.}

35. Basilodes semicuprea.

Plusia (?) semicuprea, Walker, Lep. Het. xv. p. 1787 (1858).

Rio Jutahi, 23rd January, 1875.

Although this species has the coloration of a Plusia, its structure is similar to that of B. pepita, as shown in M. Guénée's figure.

The type is a worn example without a locality.

TRANS. ENT. SOC. 1879.-PART I. (APR.) 


\section{Family CALPID AE.}

\section{Hapygia, Guénée.}

36. Hapygia smerinthoides.

Corymbia smerinthoides, Walker, Ler. Het. Suppl. iii. p. 765 (1865).

\& Boa Vista, Rio Jutahi, 1st February, 1875.

Caroia, Walker.

37. Caroia licormas.

Phalcena (Noctua) licormas, Cramer, Pap. Exot. i. pl. 74, fig. E (1779).

Bagisara bombycoides, Walker, Lep. Het. xv. p. 1792, n. 1 (1858).

Tabatinga, 29th November, 1874; Serpa, 13th February, 1875 .

\section{Diamuna, Walker.}

38. Diamuna severa.

Phalcena severa, Cramer, Pap. Exot. iv. pl. 398, fig. L (1782).

Rio Jutahi, 31 st January, 1875.

Not previously in the Collection of the British Museum.

Ecregma, Walker.

39. Ecregma modesta, n. sp.

Primaries above sericeous red-brown, densely irrorated with rosy-whitish scales, crossed by two widely divergent darker red-brown lines, the inner one transverse, at basal third, with pale yellow internal border, the outer one oblique, discal, with pale yellow external border; two small blackish spots placed obliquely at the end of the cell; some dusky streaks upon the external area; secondaries similar in colour to the primaries, but becoming whitish towards the base and with white fringe, no markings; thorax like the primaries in colour, abdomen rather paler, antennæ brown; primaries below pale pinky-brown, with creamy-white internal border; secondaries creamcoloured; body cream-coloured, slightly tinted with rosybrownish in front: expanse of wings 1 inch 7 lines.

Ilha Cuxinara, Rio Solimões, 13th October, 1874. 
Near to $E$. $\operatorname{tran}[s]$ ducta, Walker, but differing in colour and the direction of the inner line upon the primaries.

\section{Family HEMICERID E.}

\section{Hemiceras, "Guénée.}

40. Hemiceras pulverula?

Hemiceras pulverula, Guénée, Noct. ii. p. 382, 1238 (1852).

Rio Tarumá, Rio Negro, 31st July, 1874.

This species seems to be allied to Phalana gossypii of Sepp ( Surin. Vlind. pl. 23).

41. Hemiceras metastigma.

Hemiceras metastigma, Walker, Lep. Het. xii. p. 974 (1857).

Marapatá, Rio Negro, 30th December, 1874.

Near to Phalana tetrastigma of Sepp and P. meona of Cramer. Walker described the species from a very faded specimen; the natural colour of the primaries, thorax, and the margin and subanal spot of secondaries is sericeous ferruginous, tinted with greyish lilacine.

42. Hemiceras plana, n. sp.

Primaries above sericeous ferruginous, crossed by three dark-edged yellow lines; the outer border and the area between the two first lines dusky; first line near the base, transverse, not reaching the inner margin; second line nearly straight, crossing the wing at basal third, third line oblique, discal; costal margin yellow; a blackish spot at the end of the cell; secondaries sericeous brown with darker veins, fringes tipped with white; thorax ferruginous, abdomen smoky-brown; wings below sericeous, primaries below rufous isabelline, with whitish internal area and ferruginous fringe; secondaries sandy-whitish, with abbreviated rufous isabelline outer border, and small black discocellular spot; body sandy-whitish, tinted in front and behind with rufous: expanse of wings 1 inch 5 lines.

Fonteboa, Rio Solimões, 17th November, 1874.

This species has the usual subanal thickened spot common to the secondaries of the males in this genus. 
43. Hemiceras striolata, n. sp.

f Ferruginous; primaries mottled all over with little depressed striations; internal and basal areas irrorated with lilac scales; three pale-edged brown lines, the first, near the base, irregular, not reaching the inner margin; the second, at basal third, zigzag; the third, from apex to inner margin, straight and oblique; two conspicuous black dots near the centre of outer margin; secondaries paler, with golden-glossed whitish costal area and white fringe; head and collar mahogany-red, vertex cream-coloured; thorax greyish, abdomen pale ferruginous; undersurface creamy-whitish, the primaries, excepting towards inner margin, tinted with rufous, fringe dark ferruginous; secondaries, with the outer border slightly tinted with rufous; anal half of venter and upper surface of legs slightly rufous: expanse of wings 1 inch 5 lines.

Marapatá, Rio Negro, 30th December, 1874.

Although I have retained the genera Ecregma and Hemiceras provisionally in the families of Noctuites, to which M. Guénée referred them, I feel pretty sure that their true affinity is to the Notodontid genera Apela, Lophopteryx and allies; the structure of the antennæ, thorax, legs and wings are purely Notodontid.

\section{Family GONOPTERID A.}

\section{Tiauspa, Walker.}

44. Tiauspa argyria, n. sp.

Primaries silvery-brown, irrorated with rusty-brown, dotted here and there with black; three lunulated redbrown stripes, the innermost and outermost almost zigzag and slightly divergent, the central one less distinct, arched, with whitish external border; reniform linear, red-brown with whitish margins; a very irregular submarginal series of brown-edged white lituræ; secondaries, with the costal border and apical half of fringe, white; anal angle irrorated with white and dark brown and crossed by two abbreviated parallel brown lines; head, sides of thorax, and base of abdomen white, crest of thorax red-brown; abdomen pale brown; wings below greyish-brown, the costal borders and external border of primaries silvery; internal area, abdominal border of secondaries and body below sordidwhite: expanse of wings 1 inch 9 lines.

Rio Jutahi, 5th February, 1875.

Only a single example obtained. 
Cosmophila, Boisduval.

45. Cosmophila erosa.

Anomis erosa, Hübner, Samml. Exot. Schmett. Zutr. figs. 287, 288.

Serpa, in the bush, 24th April, 1874.

\section{Anomis, Hübner.}

46. Anomis grandipuncta.

Anomis grandipuncta, Guénée, Noct. ii. p. 400, 1266 (1852).

Fáro, 10th April, 1874.

\section{Family AMPHIPYRID E.}

Barydia, Guénée.

47. Barydia japeta.

Phalcena (Noctua) japeta, Cramer, Pap. Exot. iv. pl. 346, fig. G (1782).

Manaos, on board the Guajara, 2nd September, 1874.

Very incorrectly figured by Cramer; there are three pale sandy-yellowish discal spots upon the primaries, the uppermost one united to a large black spot; even this spot is incorrectly situated in the figure.

Mr. Walker, not having seen an example of B. japeta, refers it, erroneously, to the genus Safia.

\section{Amphipyra, Ochsenheimer.}

48. Amphipyra purpurascens, n. sp.

Dark greyish-brown, brightly shot with purple, spotted here and there with bright green, and speckled with black; basal fourth crossed by parallel undulated black lines; two widely divergent black-bordered pale brown stripes, forking from the centre of the inner margin to the costa, the inner one transverse, undulated, the outer one oblique, angulated and zigzag; two or three zigzag interrupted black lines just beyond and parallel to the outer stripe ; a clear yellow longitudinal line from this stripe to the end of the cell, where there are two or three brown-edged black spots; four small white costal spots towards apex; an apical pale yellow spot streaked with ferruginous; a submarginal series of greyish-bordered bracket-shaped black lituræ, connected 
by longitudinal grey dashes, with small rounded tawnybordered marginal black dots, the whole together making a series of anchor-shaped markings; a marginal series of white dots at the ends of the veins; fringe alternately ferruginous and black; secondaries pale smoky-brown, with a broad external darker border; basi-costal area silvery-whitish; fringe creamy-white, deep ferruginous at anal angle; palpi and frons purplish-brown; vertex whitybrown, with dark-brown line; thorax and collar dark brown, glossed with purple and spotted with black; abdomen smoky-brown, with whity-brown basal tufts and a dorsal tuft of dark greyish-brown close to the base ; primaries below fuliginous-brown, with pale external border; costa spotted. with pale yellow; a pale yellow apical spot, and two submarginal series of small pale yellow hastate spots; an ill-defined angulated darker central belt; secondaries sordid white, with broad external fuliginous border; a series of marginal spots, and the fringe, pale yellow; basal area, excepting towards the abdominal border, blotched with fuliginous-brown; palpi and coxæ blackish; two anterior pairs of legs dark brown, varied with black; hind legs sandy-whitish, with a black spot at the end of each joint; venter pale sandy-yellowish, or whity-brown, speckled with blackish, and with a black anal streak: expanse of wings 2 inches 4 lines.

Manaos, 6th January, 1874.

General aspect of Barydia bufo, but at once distinguishable by its shorter thicker palpi and narrower wings.

\section{Family ToxOCAMPIDE.}

\section{Athyrma, Hübner.}

49. Athyrma misera, n. sp.

Greyish-brown, with a faint lilacine tint; primaries with whitish veins; three irregular black costal spots, and a large subapical patch, dotted with white upon the costal margin, notched externally and margined internally by a black-edged pale line; a pale pinky belt before the middle, limited by two dusky-margined pale lines, reniform spot outlined in white upon a black patch, below it two duskybordered tawny spots; a submarginal series of black dots and a slender black marginal line; fringe whitish, tipped with blackish; secondaries with a diffused dusky discal 
belt; several alternate pale and blackish lines towards the anal angle; fringe and margin as in primaries; undersurface fuliginous-brown; wings with ill-defined darker discal line; fringe as above: expanse of wings 1 inch 4-5 lines.

Itatoro, Rio Madeira, 2nd June; Rio Purus, 8th September, 1874.

\section{Baniana, Walker.}

50. Baniana projiciens, n. sp.

Fuliginous-brown, the primaries tinted with lilacine, the costal border and external area whity-brown; an oblique quadrangular costal black spot near the base, a black dot followed by a small black spot in the cell and a large black internal patch, from the inferior margin of which a flap of black hair scales projects over the cell of secondaries; these black markings with slender white margins; reniform spot dark brown, with a black edge in the male, white with brown centre in the female, bounded internally by a very irregular black postmedian line; a central nebula surrounding the reniform spot and a subapical nebula upon the costa, dusky; an irregular bisinuated discal dusky line; a black marginal line; secondaries with whity-brown fringe; frons whitish, vertex and collar burnt-sienna red; prothorax chocolate-brown; undersurface pale sandy-brown: expanse of wings $\delta 1$ inch; of 1 inch 2 lines.

of Aveyros, 12th March, 1874; q Rio Jutahi, 5th February, 1875.

\section{Pasula, Walker.}

51. Pæsula nigricollis, n. sp.

Primaries pale sandy-brown, sparsely irrorated with black; an indistinct abbreviated transverse subbasal line; an irregularly-trisinuated testaceous line, interrupted by two blackish spots across the basal third; two black spots on the discocellulars; a series of black dots beyond the cell, followed immediately by a straight mahogany-brown line, with yellow internal edge, bounding internally a broad and tolerably regular grey belt; an indistinct zigzag submarginal dusky line; a marginal series of black dots; secondaries darker than the primaries, with broad grey external border; outer margin and fringe creamcoloured; a marginal series of black dots; body pale 
sandy-brown, with black collar; wings below sandywhitish, with discal blackish stripe and black marginal spots; primaries clouded with grey; secondaries with black discocellular spot: expanse of wings 1 inch 5 lines.

Manaos, 29th August, 1874.

Allied to $P$. delinquens.

\section{Family HOMOPTERID A.}

\section{Homoptera, Boisduval.}

52. Homoptera (?) zonata.

Homoptera zonata, Walker, Lep. Het. Suppl. iii. p. 878 (1865).

Mouth of Rio Jutahi, 18th January, 1875.

This species seems more like a Stimmia than a Homoptera.

53. Homoptera (?) gyrochila, n. sp.

Fuliginous-brown; primaries tinted to the middle with lilacine; crossed by three very irregular dusky lines, the first near the base, the second almost central, interrupted by a large quadrate blackish spot at the end of the cell, the third lunulate, interrupted (with pale outer margin), limiting the external border; two black dots in the cell and a marginal series; fringe dark grey; primaries below greyish-brown, the costal and outer borders irrorated with sandy-yellowish; two blackish costal dashes succeeded by sandy-yellow spots; secondaries whitish, densely speckled with greyish-brown, the disc crossed by two nearly parallel dusky irregular stripes; a blackish discocellular spot; body sandy-yellowish: expanse of wings 11 lines.

Rio Javary, 7th December, 1874.

Allied to "Homoptera" quadrisignata, but I do not feel quite satisfied that this species is rightly located in Homoptera.

54. Homoptera Trailii, n. sp.

Fuliginous-brown; wings with paler outer border traversed by a submarginal series of black-edged white dots, and limited internally by a black undulated line, which is also triundate on each wing; fringe dark grey, with a pale basal line; primaries clouded and spotted with pale brown and blackish; the central area limited on 
either side by slender very irregularly denticulate or acutely zigzag black lines, a broadly zigzag dark brown central line; cell closed by three small white spots, the central one oblong and transverse, the two others small and rounded; a dusky costal patch limited externally by the outer black line; secondaries with shining greyish basi-costal area; a white dot at the end of the cell; an irregular dusky central line, followed by an undulated black discal line; undersurface smoky-greyish, with dusky external area, blackish on secondaries, and whitishspotted border; two nearly parallel wavy discal dusky lines; primaries with whitish spots, and a cuneiform blackish spot beyond the middle of the costal border; secondaries with dusky-edged discocellular spot: expanse of wings 1 inch 9 lines.

Pariti, Rio Purus, 5th October, 1874.

Allied to $H$. integerrima, with which it agrees in marking though not in colour.

H. involuta, of Walker, is a species of Ypsia and $H$. ustipennis, a Xylis.

\section{Family HYPOGRAMMID A.}

55. Safia celia.

\section{SaFia, Guénée.}

Phalcena (Noctua) celia, Cramer, Pap. Exot. iv. p. 109, pl. 346, figs. E, F (1782).

Rio Trombetas, 2nd March, 1874.

S. celia was not previously in the Museum Collection.

\section{Yrias, Guénée.}

56. Yrias progenies?

Yrias progenies, Guénée, Noct. iii. p. 23, 1349, pl. 15, fig. 10 (1852).

Lake Juruty, 2nd April, 1874.

As we do not possess examples of $Y$. progenies from the West Indies to compare with the Amazonian specimen, and as the latter is also a good deal rubbed, I cannot be certain of the identification; the markings are, however, very like those of the figure by M. Guénée. The species has more the aspect of a Deltoid than of a true Noctuid, still (for convenience sake) I provisionally incorporate it in this paper, following the arrangement of M. Guénée, adopted by Mr. Walker. 


\section{Odice, Hülner.}

57. Odice acharia.

Phalana (Noctua) acharia, Cramer, Pap. Exot. iv. pl. 346, C (1782).

of Manaos, 6th January; Vista linda, Rio Purus, 8th October, 1874.

Mr. Trail only took a single pair of this species, which is new to the Museum Collection. It does not appear to be congeneric with Yrias, and therefore I adopt Hübner's generic name for it. Whether $O$. pamphilia is congeneric I cannot say without seeing it. "Letis" incipiens is an allied species.

\section{Campometra, Guénée.}

58. Campometra glauca.

Phalana (Noctua) glauca, Cramer, Pap. Exot. iv. pl. 311, fig. G (1782).

Rio Jutahi, 20th, 24th and 25th January, 1875.

This, rather than Hadena, seems to be the correct place for this species; the pattern is very like that of Guénée's species.

\section{Phosphila, Hübner.}

59. Phosphila (?) tatosoma, n. sp.

Arrangement of markings somewhat as in Amphipyra sanguinipuncta (Guén. Noct. iii. pl. 18, fig. 2); primaries purplish-grey, clouded with sienna, and transversely traversed by undulating brown lines; central belt indicated by two widely divergent irregular fulvous lines broadly edged with black on both sides, the outer line lunulated and limiting the external area; a white dot on each side of the reniform spot; external border broadly dark purplish-grey with pale internal edge, a submarginal irregularly undulated buff line; costal margin interrupted by white dots; a dentate-sinuate black marginal line, followed upon the fringe by a pale buff line; fringe beyond the pale line slaty-grey, interrupted opposite to the veins by whitish dots; secondaries smoky-brown; two duskybordered indistinct whitish discal lines, which converge and are angulated towards the anal angle; marginal black line and fringe nearly as in primaries; body corresponding in general coloration with the wings, the abdomen with white posterior edges to the segments; a bifurcate 
terminal whity-brown anal tuft; undersurface smokybrown; wings crossed by two dusky-bordered indistinctly whitish discal lines; discocellulars crossed by duskymargined whitish angulated spots, beyond which on the secondaries are two very indistinct dusky streaks; fringe blackish with slender whitish basal line and whitish spots opposite to the terminations of the veins; costa of primaries sordid white, crossed by dusky dashes; internal border whitish; legs grey, the tarsi above blackish, banded with white, the anterior tibiæ clothed with long whitish hair: expanse of wings 1 inch 7 lines.

Mauhes River, 5th May, 1874.

This singular species seems allied to Phosphila ursipes of Hübner; but, as I have not seen examples of this insect, I cannot be sure of its affinity to it; some of the characters, such as the terminal anal tuft and the fan-like hairy clothing of the anterior tibiæ seem to show structural proximity to the Notodontida, but in all other respects the species agrees better with the group in which I have placed it.

\section{Cenipeta, Hübner.}

60. Cænipeta bibitrix.

Canipeta bibitrix, Hübner, Zutr. Exot. Schmett. fig. 34:3.

Lake Maracaná, 7th April; Serpa, 22nd April; Rio Madeira, 16th May; Rio Marmellos, Rio Madeira, 1st June; Boa Vista, Rio Purus, 12th September; Mamiva, Rio Purus, 29th September; near Porto Salvo, 3rd October; Rio Juruá, near the mouth, 14th November, 1874 .

This species is new to the Museum Collection; it was only known to M. Guénée by the figure.

61. Cænipeta polynoë.

Canipeta polynoё, Guénée, Noct. iii. p. 31, n. 1359 (1852).

Rio Tarumá, Rio Negro, 3rd July, 1874.

A single typical example of this species, previously only represented in the Museum Collection by a damaged pair of the Central American variety. C. feronia of Felder is a nearly allied form. 
62. Cænipeta lilacina, n. sp.

Canipeta lobuligera (part), Walker (nec Guénée), Lep. Het. xiii. p. 1091 (1857).

Differs from $C$. lobuligera in its more rounded primaries, with more numerous undulated brown lines; the pale stripes on the secondaries less distinct; wings below altogether darker; the secondaries sordid pale buff, the markings much more sharply defined than in C. lobuligera; from $C$. colliquens (which has little in common with Guénée's species) it differs in its lilacine instead of green or greenish primaries, upon which the lines are less irregularly waved, and not quite so distinctly undulated; the secondaries are also paler, less fuliginous, with much better-defined pale discal streak from the anal angle; wings below considerably paler throughout: expanse of wings 1 inch 6 lines.

São Antonio, Rio Negro, 5th July, 1874.

Under C. lobuligera, Walker also placed examples of C. aniloba.

63. Cænipeta colliquens.

Noctua semigeometra, Heliothis undulata, colliquens, Hübner, Zutr. Exot. Schmett. figs. 117, 118.

Canipeta lobuligera + ? Guénée, Noct. iii. p. 32, n. 1360 (1852).

f Sepatiny, Rio Purus, 26th September; 9 Rio Javary, 4th December, 1874. Not previously in the Museum Collection.

\section{Cænipeta aniloba.}

Canipeta aniloba, Guénée, Noct. iii. p. 33, n. 1361 (1852).

Rio Tapajos, $4^{\circ} 20^{\prime}$ S., 14th March; Borba, 14th May; Barcellos, Rio Negro, 30th June, 1874.

65. Cænipeta dimidiata, n. sp.

Primaries with the basal half, up to the first black discal line, bright pale green; external half and abbreviated fascia enclosing the reniform brown, brilliantly shot with purple; black and brown transverse irregular lines almost as in $C$. lobuligera; secondaries orange, more or less streaked and clouded with grey in the male; a broad tapering submarginal black band, uniting with a marginal series of elongate black spots towards the 
apex ; fringe in the males more or less sordid externally; body greyish-brown, posterior margins of abdominal segments whitish or orange; wings below ochraceous; primaries with the external half purplish-brown, the markings ill-defined, an ochraceous costal spot; secondaries with the usual markings, but the central black lines ill-defined; pectus and underside of legs white; knees broadly black above and ochraceous at the sides; tarsi above pale buff, the anterior pair banded with black, the others with reddishbrown: expanse of wings 1 inch $4-5$ lines.

Abacaxis River, 30 miles from the mouth, 10th May; Pariti, Rio Purus, 5th October; São Paulo, 26th November; below Tabatinga, 28th November, 1874.

\section{Hypogramia, Guénée.}

66. Hypogramma suttea.

Canipeta suttea, Guénée, Noct. iii. p. 30, n. 1357 (1852).

Mouth of Rio Sapó, 13th December, 1874.

If, as I believe, I have rightly identified this species, its resemblance to Canipeta bibitrix is purely superficial, and the insect is in reality a Hypogramma.

67. Hypogramma damonia.

Phalcena (Noctua) damonia, Cramer, Pap. Exot.iv. p. 71, pl. 324, figs. B, C (1782).

Phalena sulima, Stoll, Suppl. Cramer, p. 175, pl. 40, figs. 5, 5 C (1791).

Sepatiny, Rio Purus, 29th September; Mabidiry, 30th September; Rio Juruá, 26th October; Curimatá, 30th October; Uruçaca, 1st November; Rio Juruá, 7th November; Gavião, 10th November; Rio Javary, 3rd December, 1874; Rio Jutahi, 30th January; Boa Vista, 1st February, 1875.

One of the commonest of all New World Noctuids : it varies slightly in the more or less strongly-defined black line upon the white belt of primaries; in some examples it is very indistinct, giving a different aspect to the insect. 


\section{Family CATEPHIID A. \\ Stictoptera, Guénée.}

68. Stictoptera subaurata.

Stictoptera subaurata, Walker, Lep. Het. xiii. p. 1132, n. 5 (1857).

Stictoptera phryganoides, Walker, l. c. xv. p. 1812 (1858).

Nagara steirialis, Walker, l. c. Suppl. 4, p. 1379 (1865).

Rio Negro, 4th July; Marapatá, 30th December, 1874 ; Manaos, 3rd January; Rio Jutahi, 3rd and 5th February, 1875.

\section{Cocytodes, Guénée.}

69. Cocytodes schneideriana.

Phalcena schneideriana, Cramer, Pap. Exot. iv. p. 37, pl. 308, fig. A (1782).

Rio Jutahi, 27th January, 1875.

Allied to C.immanis; what M. Guénée and Mr. Walker were about to refer this thick-bodied and altogether robustlooking moth to the genus Letis I cannot imagine; the only excuse for Mr. Walker is that he probably blindly followed M. Guénée, and there being no example of Cramer's species in the collection, never afterwards discovered his error.

\section{Family BOLINID Æ. \\ Bolina, Guénée.}

70. Bolina fasciolaris.

Adia fasciolaris, Hübner, Zutr. Exot. Schmett. figs. $443,444$.

Near Santa Cruz, Rio Solimões, 9th December, 1874.

71. Bolina cunearis.

Bolina cunearis, Guénée, Noct. iii. p. 70, n. 1414 (1852).

Maricá, Rio Madeira, 23rd May; Curimatá, Rio Juruá, 30th October, 1874.

The Amazonian examples are all referable to the more prevalent form of the species described by M. Guénée as var. A. 


\section{Family HYPOCALID A.}

\section{Hypocala, Guénée.}

72. Hypocala andremona.

Phalcena (Noctua) andremona, Cramer, Pap. Exot. iv. pl. 358, C, D (1782).

Hypocala filicornis, Guénée, Noct. iii. p. 76, n. 1421, pl. 13, fig. 7 (1852).

Boa Vista, Rio Purus, 12th September; Rio Juruá, 6th November, 1874; Barreira branca, Rio Jutahi, 3rd February, 1875.

I have no doubt that $H$. andremona, as figured by Cramer, is a highly-coloured form of the widely-ranging H. filicornis. The examples taken by Dr. Trail agree in all respects with M. Guénée's figure.

\section{Family OPHIDERID A.}

\section{Ophideres, Boisduval.}

73. Ophideres scabellum.

Ophideres scabellum, Guénée, Noct. iii. p. 117, n. 1488 (1852).

Gavião, Rio Juruá, 10th November, 1874.

A single male of this species, the female of which only was previously in the British Museum.

\section{Family EREBID AE.}

\section{Vogia, Walker.}

74. Vogia amplivitta.

Vogia amplivitta, Walker, Lep. Het. xv. p. 1818, n. 1 (1858).

Azeta (?) pertinax, Felder, Reiseder Nov. Lep. iv. pl. 99, fig. 1 .

Aruman, Rio Purus, 9th September, 1874; Boaventura, Rio Jutahi, 24th January, 1875.

Apparently a rare species: it seems quite out of place in the family to which Walker has referred it. 


\section{Gigia, Walker.}

75. Gigia obliqua.

Gigia obliqua, Walker, Lep. Het. Suppl. iii. p. 942 (1865).

Brotis (?) stenogaster, Felder, Reise der Nov. Lep. iv. pl. 119 , fig. 5 .

Uttary, Rio Purus, 25th September, 1874.

Walker's type is a rather worn specimen without a locality.

\section{Blosyris, Hübner.}

76. Blosyris despecta.

Brujas despecta, Walker, Lep. Het. xv. p. 1819 (1858).

Abacaxis River, 10th May, 1874.

The fairly perfect example taken by Dr. Trail proves this species to be a Blosyris allied to B. abadirina; it may be the Phalana-Noctua scolopacea of Cramer (pl. $174, \mathrm{C})$.

77. Brujas helima.

Phalcena (Noctua) helima, Cramer, Pap. Exot. iv. p. 40, pl. 309, fig. D (1782).

Manaos, 22nd December, 1874.

Walker is wrong in referring this species to Blosyris; it is allied to Brujas posterior from Jamaica.* I am certain that no specimen ever was (as Cramer asserts) taken at Sierra Leone.

\section{Letis, Hübner.}

78. Letis occidua.

đ. Phalana-Bombyx occidua, Linnæus, Syst. Nat p. 812 , n. 14 ; Clerck's Icones, pl. 54, figs. 1, 2.

. Phalana-Noctua corisandra, Cramer, Pap. Exot. iv. p. 189, pl. 384, figs. A, B (1782).

Pará, 6th March, 1875.

This species seems to be rare; we previously only possessed a much-injured example without locality.

* A nearly allied species, $B$. rengus, from St. D mingo, is identical with Letis intracta. Letis incipiens (the species which succeeds it in the Catalogue) is identical with Xylis ('Homoptera') ustipennis. 
79. Letis marmorides.

9. Phalca (Noctua) marmorides, Cramer, Pap. Exot. i. p. 25, pl. 16, figs. E, F (1779).

On board the Yeamiaba, 26th August, 1874.

Not previously in the Museum Collection: it is allied to the preceding species and to "Brujas" maculicollis ; it may possibly be an extreme variety of L. occidua, 오.

80. Letis integra.

Letis integra, Walker, Lep. Het. xiv. p. 1273, n. 24 (1857).

Syrnia letiformis, Guénée, Noct. iii. p. 158, n. 1549 (1852).

Mouth of Rio Jutahi, 18th January, 1875.

If Syrnia be a distinct genus from Letis, which I doubt, the difference exists in its shorter and more strongly-denticulated wings, which, in fact, are the only distinctions pointed out by M. Guénée; it therefore stands to reason that Syrnia letiformis is an anomaly. The species is nearly allied to Letis xylia and L. scops; Syrnia mineis is also a Letis.

81. Letis alauda.

Letis alauda, Guénée, Noct. iii. p. 154, n. 1543 (1852).

8. On board the Yeamiaba, 17th August; Manaos, 22nd December, 1874.

This species is new to the National Collection; it is somewhat nearly allied to the preceding, but much larger, and the female is broadly clouded with testaceous, this colour occupying the whole central area of the secondaries.

\section{Letis Trailii, n. sp.}

q. Allied to the preceding species, but much darker, with the markings more sharply defined; fuliginous-brown, irrorated with stramineous; wings crossed in the centre by six parallel dentate-sinuate dark-brown or black lines, the area enclosed by which is wholly testaceous in the secondaries, so as to form a broad central belt, but only the external border of which is testaceous on the primaries; basal area of primaries crossed by two irregularly undulated pale-bordered blackish lines; a white costal spot beyond the cell, between which and the apex are three or

TRANS. ENT. SOC. 1879.-PART I. (APR.) 
four whitish dots; disc crossed by an ill-defined dentatesinuate blackish stripe, bounded externally, on first median interspace, by a testaceous $>$-like character; two parallel zigzag black submarginal lines; discoidal spots brown, with black margins, the "orbicular" slightly elliptical in form, the "reniform" D-shaped; secondaries with brown discocellular spot, speckled with testaceous and edged with black; an angular testaceous marking on the basi-abdominal area; disc crossed by a slightly-undulated arched black stripe, bounded externally at apex by a diffused testaceous patch, and upon the first median interspace by a dasb of the same colour; two undulated black submarginal lines; body brown, varied with black, the abdomen with whitish-bordered black segmental bars interrupted in the centre by whitish spots; undersurface grey, white, and black, much as in $L$. alauda, the discoidal spots dark and well-defined, both wings crossed beyond the middle by a black-bordered angulated white belt; several white discal spots; fringe varied with white; secondaries crossed in the centre by three slender parallel irregular brown lines, the middle one indistinct; basal area greyish-white; body below whitish, venter white: expanse of wings 4 inches 4 lines.

Boaventura, Rio Jutahi, 24th January, 1875.

Dr. Trail, unfortunately, only obtained one example of this fine species. All the species of Letis seem to be rare.

83. Letis confundens.

. Syrnia confundens, Walker, Lep. Het. xiv. p. 1279 , n. 6 (1857).

§. On board the Yeamiaba, 27th August, 1874.

Allied to the preceding, but considerably smaller and more uniformly fuliginous on the upper surface; the form of the male at once decides the generic position of this species.

\section{Latebraria, Guénée.}

84. Latebraria janthinula.

Latebraria janthinula, Guénée, Noct. iii. p. 160, n. 1551 (1852).

Pará, 8th March, 1875.

A single example only of this rare and beautiful species.

Following Walker's Catalogue, it would be necessary here to introduce Crinodes, referred by that author to the 
Noctuites, but actually belonging, as I find, to the Notodontida ; to the latter family Bardaxima also belongs; it is closely allied to, if distinct from, Etobesa.

\section{Family POAPHILID A. \\ Phurys, Guénée.}

85. Phurys lineolaris.

Noctua lineolaris, Hübner, Eur. Schmett. Noct. fig. 454 .

Uricurituba, Rio Tapajos, 17th March, 1874.

"Phurys" biangulata of Walker is a Heteropygas; an example of this species from Santarem was confounded with $P$. basilans of Guénée, which it resembles in colouring. P. contenta, Walker, is identical with Poaphila scita of the same author, and must be referred to the genus Hemiceras, being evidently nearly allied to $H$. linea, Guénée. Phurys garnoti of Guénée, although it has the general aspect of Trigonodes maxima, seems structurally more nearly allied to the other species of Phurys. $P$. inficita would be better placed in Poaphila.

\section{Family REMIGIID AE.}

\section{Remigia, Guénée.}

86. Remigia latipes.

Remigia latipes, Guénée, Noct. iii. p. 314, n. 1774 (1852).

Mauhes River, 1st May, 1874.

\section{Catamelas, Rogenhofer.}

87. Catamelas caripina.

Catamelas caripina, Felder and Rogenhofer, Reise der Nov. Lep. iv. pl. 119, fig. 21 (1874).

Uttary, Rio Purus, 25th September, 1874.

A very singular species, in which the undersurface is fully twice as dark as the upper. It is new to the Museum Collection.

The Phalana brunnea of Cramer (cclxxxvii. G.) seems to be a nearly-allied species. 


\section{Epidromia, Guénée.}

88. Epidromia signata, n. sp.

Pale brownish salmon-colour, sparsely speckled with black scales; external border of wings olive-brown, diffused internally, discal area slightly washed with pale lilacine; primaries with a black costal dot above the cell and two spots just beyond the cell ; reniform almost pyriform, jet black with slender white margin; a submarginal series of indistinct dusky spots; secondaries with sericeous whitish costal border; a discal transverse series of black dots; head and collar slightly lilacine; secondaries below and internal border of primaries pale flesh-coloured; all the wings with a curved discal series of black dots almost connected by a series of black lunules immediately beyond and between them; a pale-edged discocellular black dot; venter and sides of pectus pale: expanse of wings 1 inch 6 -8 lines.

․ Mabidiry, Rio Purus, 30th September; Rio Juruá, 31 st October, 3rd November; Rio Javary, 6th December, 1874 .

89. Epidromia rivularis, n. sp.

s. Pale ferruginous-brown, striolated with grey, with dark external border; discal area slightly washed with lilacine, whitish; reniform 8-shaped, the upper half being whitish with brown margin, and the lower half jet black with whitish margin; a crinkled whitish line beyond the cell on the secondaries dotted internally with black; a submarginal series of whitish-dotted dusky spots, very illdefined on the secondaries; bases of the sinuations of the fringe pale; wings below, as in Obroatis negata, very pale smoky-brown; the upper surface of legs, outer surface of palpi and discoidal area of primaries dull red; wings with a curved discal series of black dots almost connected by a series of black lunules just beyond and between them; fringe dark brown: expanse of wings 1 inch 10 lines.

Rio Juruá, 27th October, 1874.

Unfortunately Dr. Trail only obtained one example of this species.

90. Epidromia negata.

Obroatis negata, Walker, Lep. Het. xv. p. 1635, n. 1 (1858).

Mamiva, Rio Purus, 28th September; Rio Juruá, 
$4^{\circ} 40^{\prime}$ S., $66^{\circ} 40^{\prime}$ W., 29th October; Pupunha, 5th November; Gavião, 10th and 12th November; below Tabatinga, 28th November; Marapatá, Rio Negro, 30th December, 1874; Boaventura, Rio Jutahi, 24th and 26th January; Boa Vista, 1st February, 1875.

The type of this species is somewhat aberrant, the reniform being represented by a slender whitish-edged black litura; it is also faded, and thus much resembles a Toxocampid; fresh examples are much darker in colour, and the ten specimens taken by Dr. Trail agree in having the discoidal spots pale greenish-yellow with dusky margins.

\section{Epidromia columba, n. sp.}

Pale bronzy-olivaceous; wings with a diffused discal belt of greyish-lilacine; an oblique line just beyond the discoidal cells, ill-defined on the secondaries, but sharply defined and laky-brown, with an incurved subangulation just beyond the reniform spot, on the primaries; a discal series of black dots united by grey semicircles into a crinkled line upon the primaries; an ill-defined submarginal series of whitish dots; primaries with two triangular black costal spots; reniform spot D-shaped, pale greenishyellow with black margin and enclosing an oblique B-shaped marking; orbicular punctiform, black; secondaries with the costal area pearly-white; abdominal fringe white; abdomen pearly-greyish, whitish towards the anus, undersurface altogether paler than above, primaries pale sandy-yellowish, with brown external border, black discoidal dots, discal crinkled line as above, and pearly internal area; secondaries with whitish abdominal area, apex and outer margin brown, a black discocellular dot and a discal series of black dots; body below whitish, legs pale reddish-brown: expanse of wings 1 inch 8 lines.

\section{Guará, Rio Solimões, 22nd October, 1874.}

A beautiful soft-looking species, of which unhappily only a single example was obtained.

\section{Epidromia distincta, n. sp.}

Purplish-brown, with the external fringes and the veins on the disc of the primaries reddish; a discal series of black dots united by a castellated whitish line; external border greyish, limited internally by a very ill-defined whitish squamose line (the only traces of which in one 
example are a series of blackish-edged white dots on the primaries); these wings with small white-edged black orbicular spot; reniform also black and white-edged, but very large and excised in front; postdiscoidal area, some costal spots, a squamose irregular subbasal line, and an apical spot whitish ash-colour; secondaries with an illdefined greyish discal band parallel to the outer margin; costal area pale sericeous-brown; anus pale buff; undersurface pale smoky-brown, with dusky discocellular dots: expanse of wings 1 inch 10 lines.

Pupunha, Rio Juruá, 5th November; Braga, Rio Javary, 7 th December, 1874.

Only a pair of this striking species was obtained.

93. Epidromia ocellata, n. sp.

Lilacine-brown ; the outer borders of the wings chocolatebrown, diffused internally; a discal curved series of white dots with black internal margins; a submarginal ill-defined series of whitish dots; primaries with an irregular series of white dots across the basal area; two blackish costal dashes above the end of the cell; orbicular wanting; reniform large and irregular, excised in front at the upper angle, jet black with a white margin; secondaries with a black discocellular ocellus with creamy-white iris and W-shaped pupil; head and collar darker than the thorax, abdomen paler ; primaries below rust-red; internal border sericeous whity-brown; a dot in the cell, two on the discocellulars and a discal series, connected externally by a crinkled greyish-white line, black with greyish-white margins; a greyish-white apical spot; secondaries whitybrown speckled with black, suffused with rust-red, which increases in intensity towards the apical border, which is as red as the primaries; a discocellular black dot and discal series as in the primaries; pectus whitish, coxæ and external fringes of the femora and tibiæ rust-red; external surface of the palpi, upper surface of anterior tibiæ and the tarsi above chocolate-brown, the latter banded with white: expanse of wings 1 inch 8 lines.

Mamiva, Rio Purus, 28th September, 1874.

Only a single example obtained.

\section{Ceromacra, Guénée.}

94. Ceromacra tymber.

Phalana tymber, Cramer, Pap. Exot. ii. p. 190, pl. 167, fig. D (1779). 
Itaituba, 15th March; on board the Yeamiaba, 11th August; on board the Guajara, mouth of Rio Purus, 6th September; Manaos, 7th September; Jurucua, Rio Purus, 24th September; Hyntanaham, 27th September; Rio Juruá, 27th October; Pupunha, 5th November; Juruapuca, 11th November; Rio Tabatinga, 29th November; Marapata, Rio Napo, 31st December, 1874; Boaventura, Rio Jutahi, 24th January; Rio Jutahi, 5th February, 1875.

This apparently common species is new to the Museum Collection.

\section{Ceromacra fuliginea, n. sp.}

§. Fuliginous, primaries paler than the secondaries, bronzy; an irregular dusky streak across the basal third, an angular blackish spot on the discocellulars, and an angulated dusky discal line a little beyond the cell; a black subbasal spot; a large sordid white apical spot; secondaries with whitish costal border; head lilacine; anal tuft testaceous; wings below pale sericeous greyishbrown; discocellulars dusky; primaries with whitish interno-basal border; body below whitish; tarsi above blackish, banded with white: expanse of wings 2 inches.

․ Chocolate-brown, uniformly coloured; markings of primaries indistinct, apical spot small and obscure; undersurface fuliginous, the primaries with rather paler internal border; discocellulars slightly dusky; tarsi above blackish, banded with testaceous: expanse of wings 2 inches 1 line.

․ Lagas, mouth of Rio Negro, 5th August; 8 , Sepatiny, Rio Purus, 29th September, 1874.

Before leaving the present family I may note that Massava scissa of Walker is Isogona continua of Guénée.

\section{Family FOCILLID $\mathbb{E}$.}

All Amazonian or New World forms, referred by Walker to the first genus of this family (Zethes), may be placed under Ephyrodes; as, for instance, Z. quatiens, to which "Focilla" decolor is nearly allied. 


\section{MaZACYla, Walker.}

96. Mazacyla abydas.

Noctua abydas, Herrich-Schäffer, Auss. Schmett. App. fig. 565 (1869).

Sepatiny, Rio Purus, 29th September; Pariti, 5th October; Pupunha, Rio Juruá, 5th and 6th November; Pupunhazinho, 8th November, 1874; Boaventura, Rio Jutahi, 1st February; Barreira branca, 3rd February, 1875 .

Mazacyla fusifera is synonymous with Focilla relata.

\section{Azatha, Walker.}

97. Azatha marcellina.

Phalcena (Noctua) marcellina, Cramer, Pap. Exot. iv. p. 48, pl. 312, fig. F (1782).

Rio Purus, 23rd September, 1874.

Not previously in the Museum, but closely allied to A. retardens.

\section{Tautobriga, Walker.}

98. Tautobriga euspila.

Tautobriga euspila, Walker, Char. Undescr. Lep. p. 56 , n. 93 (1869).

Amphigonia (?) erythropus, Felder, Reise der Nov. Lep. iv. pl. 118, fig. 25 (1875).

§. Manaos, i3th June, 1874.

The type is a somewhat worn female, without antennæ, from Limas. The genus is, in my opinion, intermediate in character between Focilla and Milyas; but I must admit that I regard the Focillidee and Amphigoniidee as too closely related for separation; the only structural difference pointed out by M. Guénée is a slight modification of the palpi, scarcely sufficient in some instances to separate the species generically: no other difference of the slightest value is indicated.

Focilla Guérini, Guénée, is closely allied to Amphigonia costalis, Walker. Both species would be better placed in Azatha; as also probably Focilla Ghiliani (which, however, I have not seen). Amphigonia? rudis of Walker is a Nedusia (Geometrites). 
Lacera, Guénée.

99. Lacera amazonica, n. sp.

Fuliginous-brown, varied with red-brown and shot with lilacine; primaries darker than the secondaries, greyish in general tint; crossed by irregular black lines; the costal border, almost to the apex, sordid whitish, interrupted by the black lines, and one or two dark-brown dashes; basal area speckled with whitish; an irregular whitish belt, bounded by sinuated black lines from the cell to the inner margin ; reniform greyish, enclosing a small blackedged whitish spot, and margined with whitish; a broad black-bordered oblique lilacine belt from the reniform spot to the external angle; secondaries reddish towards external border; costal area bronzy; an internally white-edged black spot, in some lights brilliantly shot with ultramarine blue, at apex; a dusky spot at the end of the cell; base of the cell and the disc crossed by alternately black and reddish-brown zigzag lines; two widely-separated alternately black and buff longitudinal dashes between the first median and the abdominal margin; a black oblique discal streak from the anal angle; a macular submarginal black line; thorax red-brown; abdomen blackish, with testaceous edges to the segments; undersurface sordid stramineous, densely speckled with black, disc and outer margin clouded with chocolate-brown, and crossed by two or three undulated black lines; primaries with a pearlywhite subapical spot; secondaries with two zigzag blackish lines forming the edges of an ill-defined dusky belt, which crosses the cell; a submarginal cinereous belt bounded internally by an undulated blackish line; apical spot as above: expanse of wings 1 inch 10 lines to 2 inches 1 line.

§. Rio Jutahi, 25th January ; \& Santarem, 4th February, 1875 .

Only a single pair was obtained of this species; it is nearly allied to "Homoptera" pacifica of Walker, but is structurally better placed in Lacera than in Homoptera.

\section{Amphigonia, Guénée.}

100. Amphigonia placida, n. sp.

Greyish-fuliginous, the wings above shot with lilac; primaries crossed by three ill-defined dusky stripes, the two first of which are united, so as to form a loop, upon 
the costai margin, third stripe sigmoidal; secondaries crossed in the centre by two reddish-brown subangulated stripes, the lower half of the area between which is pale ferruginous; two or three white-speckled black spots in an oblique series parallel to the anal half of the outer margin, the latter slightly excavated; thorax tinted with lilacine; undersurface pale fuliginous, the secondaries whitish, excepting upon the costal and external borders; a nearly central transverse dusky line; posterior half of pectus and the venter sordid white: expanse of wings 1 inch 2 lines.

Sepatiny, Rio Purus, 29th September, 1874.

This species is slightly abnormal in form.

\section{Teratocera, Guénée.}

101. Teratucera erycata.

Phalana erycata, Cramer, Pap. Exot. iii. pl. 287, D s; iv. pl. 370, E o (1782).

Boa Vista, Rio Purus, 12th February; Paranamirim, 19th April; Rio Javary, 3rd December, 1874.

The genus Rhescipha should properly be placed next to Teratocera and not in the Limacodida (compare Trans. Ent. Soc. 1878, p. 72 ); the palpi are similar in both genera, although more developed in $R$. servia and $R$. obtusa (not in $R$. elegans).

Walker's two genera Liviana and Leida, referred to this group, are specifically identical, and are "Ephyrodes" scitilinea of the same author, and the male of "Thermesia" sigillata.

\section{Family THERMESIID A.}

\section{Argidia, Guénée.}

102. Argidia ortilia.

Phalana ortilia, Cramer, Pap. Exot. iv. pl. 344, fig. F (1782).

ô. Rio Javary, 4th December, 1874.

Probably the one example obtained by Dr. Trail is a slight variety of Cramer's species; anyway, it is too close to describe as distinct upon a single specimen : it is near to "Hypenaria" orphna of Hübner. I. am satisfied that, 
if M. Guénée is right in referring his A. palmipes to Argidia, he is wrong in referring $H$. ortilia and $H$. orphna to Hypenaria.

103. Argidia tarchon.

Phalcena tarchon, Cramer, Pap. Exot. ii. p. 65, pl. 139, fig. C (1779).

Azirista intracta, Walker, Lep. Het. xv. p. 1639, n. 1 (1858).

Argidia subrubra, Felder, Reise der Nov. Lep. iv. pl. 118, fig. 28 (1875).

Juruana, Rio Purus, 24th September; near Santa Cruz, Rio Solimões, 9th December, 1874.

This species is so nearly allied to $A$. calus, of Guénée, that at first I hesitated as to whether or not it was distinct; yet this author refers it to Thermesia.

104. Argidia obliterans.

Plaxia obliterans, Walker, Lep. Het. xv. p. 1627, n. 6 (1858).

Ayrão, Rio Negro, 3rd July, 1874.

This species has all the characteristics of Argidia; it differs entirely in form and structure from Plaxia, the type of which is $P$. macarea.

The Apistis of Felder (part Hübner) represents typical Plaxia. I think it very doubtful whether M. Guénée's second species, P. hypenoides, is congeneric with $P$. macarea, as he states that the wings are angular: this is hardly true of Cramer's insect.'

105. Argidia subvelata.

+. Hypernaria (sic) subvelata, Walker, Lep. Het. Suppl. p. 1082 (1865).

§. Argidia aganippe, Felder, Reise der Nov. Lep. iv. pl. 118, fig. 27 (1875).

Pupunha, Rio Juruá, 5th November, 1874.

The single example taken by Dr. Trail differs from Walker's type in the coloration of the undersurface of the primaries, the ground-colour being fuliginous-brown, with the reniform spot and a broad nebulous costal border, as far as the second or discal line, bright ochreous. The type has the ground-colour wholly ochreous, which seems also to be the case with Felder's example; Dr. Trail's specimen is, therefore, an interesting variety. 
106. Argidia rosacea, n. sp.

Form and general pattern above of $A$. tarchon, but clay-coloured, washed with rose-colour, the lines towards the base and discoidal spots less distinct; wings below orange, washed with rust-red towards the apex and outer margin of secondaries; the primaries, with the exception of a broad costal streak and the internal border, washed with the same colour; apical border pearly-white, limited internally by a submarginal oblique brown-edged snowwhite line; apical fringe white, remainder of fringe in all the wings brown; the extrabasilar and discal lines dark brown; discoidal spots barely indicated by brown dots; body ochraceous, legs orange; tibiæ of posterior legs broadly fringed: expanse of wings 1 inch 8 lines.

Uricuri, Rio Purus, 2nd October, 1874.

A single example of this pretty species, which seems most nearly allied to $A$. palmipes.

\section{Orthogramma, Guénée.}

The type of this genus, O. coppryi, was subsequently described by Walker as Epitausa latabilis. As he had wrongly identified Guénée's species, this might have been considered a venial offence; but there is no excuse for his describing the male of the species regarded by himself as O. coppryi under the name of Archana certa and the female as Azeta apicifera; the latter and Thermesia guttularis are species of Orthogramma.

O. vacillans of Walker is identical with Plaxia ingenua of the same author, and allied to "Thermesia" scalena of Felder.

107. Orthogramma pavescens, n. sp.

Very pale olive-brown or stone-colour; wings crossed, from apex of primaries to middle of abdominal margin of secondaries, by a well-marked, externally whitish-edged, chocolate-brown, straight line; area immediately beyond this line washed with silver-grey; a discal series of connate black and white dots; fringe grey; primaries with barely-distinguishable discoidal spots; head and antennæ chocolate-brown; undersurface fuliginous-brown; primaries whitish towards apex and outer margin; a submarginal series of black dots; secondaries crossed by a 
dark wavy discal line; apex dark: expanse of wings 1 inch 8 lines.

Rio Jutahi, 5th February, 1875.

Seems allied to $O$. livescens of Guénée.

108. Orthogramma lurida, n. sp.

Dull laky-brown; the wings crossed, from near apex of primaries to near abdominal margin of secondaries, by a straight dark-chocolate line; primaries crossed transversely near the base by a falciform dark-brown line; orbicular spot punctiform, white with brown edge; reniform represented by two slender opposed bisinuate brown lines; costal edge orange ; fringe ochraceous; all the wings with an arched discal series of elongated ferruginous dots; secondaries with stramineous costal border; fringe dull clay-coloured; palpi and tibiæ of posterior legs chocolatebrown; tarsi blackish; wings below pale clay-coloured, suffused in the centre, and on external area of secondaries, with pale smoky-brown; a central dusky line, from costa of primaries to abdominal margin of secondaries; discocellulars blackish; primaries with a blackish dot in the cell; inner border pale and sericeous; body below whitish: expanse of wings 1 inch 9 lines.

\section{Amazons.}

Exact locality and date obliterated.

109. Orthogramma ignilinea.

Thermesia ignilinea, Walker, Lep. Het. Suppl. iii. p. 1046 (1865).

Ayrão, Kio Negro, 3rd July, 1874.

Dr. Trail only obtained one example of this rare species; the type is a broken specimen.

M. Guénée regards his genera Sanys and Thiona as nearly allied to Orthogramma; in their slender Geometridlike bodies and antennæ they much more nearly approach Thermesia.

\section{Thermesia, Hübner.}

Before proceeding to the enumeration of Dr. Trail's specimens, it is most important to correct the numerous errors, chiefly generic, which Mr. Walker has fallen into in this group of species.

Thermesia sigillata is a Liviana, T. prospera a Capnodes, T. moniliaris (= Phurys arenosa) a Capnodes, 
T. subrutilans a Capnodes, T.alacris a Liviana, T. torrida a Gerisa (=G. discerpta), T. ignilinea an Orthogramma, T. bipunctata an Ephyrodes, T. guttularis an Epitausa, T. croceiceps a Dagassa, T. generatrix an Orsa, $T$. arenacea $=T$. consocia $=T$. retrahens,${ }^{*} T$. vaga an Egnasia, T. despecta a Bithiasa, T.transducta an Azazia (= A. rubricans), T. simplex an Iluza (=I. decisa), $T$. finipalpis a Capnodes, $T$. reticulata $=T$. scitaria.

Formerly I used to wonder at the facility with which $\mathrm{Mr}$. Walker would settle the generic and frequently the specific location of any insect which was shown to him; I have ceased to wonder now.

\section{Thermesia gemmatalis.}

Thermesia gemmatalis, Hübner, Samml. Exot. Schmett. Zutr. figs. 153, 154.

var. Remigia subsignata, Walker, Lep. Het. xv. p. 1846 (1858).

Serpa, in the bush, 21st April, 1874.

\section{Azeta, Guénée.}

The type of this genus is $A$. uncas, which is identical with Hypernaria (sic) continuens of Walker.

\section{Azeta turbida, n. sp.}

Brownish-ochreous; the primaries washed with rosylilac, with a large almost semicircular castaneous costal patch between the cell and apex; three dusky transverse lines, the first straight, the second sinuated, the third oblique, and limited internally by a blackish-edged ochreous line; a discal series of white-speckled black dots; a blackishedged white discocellular lunule; secondaries with two dusky lines, the inner one oblique, the outer straight and limited as in the primaries by a dark-edged ochreous line; a discal series of white-speckled black dots; fringe dusky; abdomen rose - tinted; undersurface fuliginous - brown, crossed beyond the middle by a dusky stripe; primaries with pale outer border ; terminal joint of palpi, bases of tibial spines and tarsal joints cream-coloured: expanse of wings 1 inch 9 lines.

Mamiva, Rio Purus, 28th September, 1874.

Allied to $A$. uncas, only one example obtained.

* This species belongs to one of M. Guénée's genera, identified by Mr. Moore, who will probably shortly publish the correction. 
Pangrapta, Hübner.

112. Pangrapta repugnalis.

5. Pangrapta repugnalis, Hübner, Samml. Exot. Schmett. Zutr. figs. 575, 576 .

․ Azeta vampoa, Guénée, Noct. iii. p. 360, n. 1834 (1852).

§. Azeta rhodogaster, Guénée, l. c. n. 1835.

var. ₹, \&, Azeta mirzah, Guénée, l. c. n. 1836.

8. Chabora undulifera, Walker, Lep. Het. Suppl. iii. p. 1114 (1865).

8. Serpa, in the bush, 22nd April, 1874.

I have no doubt whatever that the whole of the above are very slight variations of this variable and common species.

Walker has described the above as a second genus under the name of Chabora in the next volume of his Catalogue, p. 1184.

Azeta quassa has nothing to do with the genus, but is identical with Massala dimidiata (Suppl. iii. p. 977).

A. hypopyrina, of Felder, belongs to Pangrapta, as also his $A$. leucoma.

A. obvertens (= Capnodes turtur, Felder) belongs to the genus Capnodes.

\section{Helia, Hübner.}

113. Helia calligramma.

Helia calligramma, Hübner, Exot. Schmett. Zutr. figs. $157,158$.

Homoptera (?) albirena, Walker, Lep. Het. Suppl. iii. p. 891 (1865).

Pariti, Rio Purus, 5th October; Rio Sapó, 21st November, 1874 .

Walker has wrongly referred this species to Canipeta; it seems very close to $S$. anguinna, of Felder.

\section{Metalectra, Hübner.}

114. Metalectra dotata.

Homoptera dotata, Walker, Lep. Het. xiii. p. 1067, n. 32 (1857).

Serpa, in the bush, 24th April; Abacaxis, 12th May; Humayta, Rio Madeira, 23rd May; Rio Javary, 8th 
December, 1874; Rio Jutahi, 5th February, 1875; Serpa, 13th February, 1875.

Allied to "Homoptera" quadrisignata, and perhaps to "H." zonata, previously noted under Homoptera. (See p. 40.)

\section{Metalectra (?) ypsilon, n. sp.}

Slaty-grey varied with testaceous, and with well-defined black discoidal spots; "reniform" crescent-shaped; a large pyramidal testaceous patch, interrupted by a black costal spot (so as to make a $\mathbf{Y}$-shaped marking), immediately beyond the cell of primaries; a partly black-edged zigzag testaceous line from the $\mathbf{Y}$-shaped marking to the inner margin; a submarginal series of black and testaceous dots; secondaries with the basal two-thirds testaceous, clouded with sienna-reddish and speckled with black; submarginal dots as in primaries; undersurface shining whity-brown, with indistinct traces of the markings of the upper surface: expanse of wings 1 inch 3 lines.

Tunantins, 23rd November, 1874.

Only one example obtained: the undersurface is not unlike that of "Homoptera" zonata.

"Homoptera" scitior $=H$. perpusilla may be referred to Metalectra.

\section{Mulelocha, Walker.}

116. Mulelocha extranea. Homoptera (?) extranea, Walker, Lep. Het. Suppl. iii. p. 881 (1865).

Mulelocha frontalis, Walker, l. c. p. 1103. var. Blanona dives, Walker, l. c. p. 1106.

Mamiva, Rio Purus, 28th September; Sepatiny, 29th September; Rio Solimões, 17 th October; Uruçaca, Rio Juruá, 9th November, 1874.

Allied to Selenis compacta of Felder, which may even be an extreme variety of it.

"Homoptera" ocellata is allied to Mulelocha*, it certainly has nothing in common with Homoptera; it resembles, in the ocellation of the primaries, Dialithis dioptica, Walker (= Cyclopteryx (?) macrops, Felder).

* The palpi, however, are much thicker, shorter and curved backwards as in Metalectra; to this genus it would be most safely referred. 


\section{Tyrissa, Walker.}

117. Tyrissa (?) laminata, n. sp.

Pearly-greyish, the primaries with the costal half washed with chocolate, basi-costal area of secondaries tinted with chocolate; numerous oblique white-edged black or chocolate irregular lines from the costal margin of primaries to abdominal margin of secondaries ; fringe chocolate-brown, costal border of primaries spotted with whitish; undersurface whity-brown; wings crossed by rusty-brown dentate-sinuate parallel lines; external border purplishgrey, interrupted in the middle on the primaries; costal border white, interrupted by black and red-brown lines and dashes: expanse of wings 1 inch 1 line.

Manaos, 11th February, 1875.

Only one example was obtained.

118. Tyrissa notiaphila, n. sp.

Wings sordid sandy-yellow, irrorated with grey towards the base, crossed by four equidistant parallel dark-brown dentate-sinuate lines; costal edge black, dotted with white, external third irregularly slaty-grey, intersected by an irregular undulated whitish line; a marginal series of black dots; fringe white, dotted with grey; secondaries with the base white, a greyish curved submarginal grey stripe, bounded externally by a zigzag whitish line; external border whity-brown; a series of black marginal dots; body grey; primaries below greyish-brown, secondaries white, with greyish-brown costal area; discoidal spots and edge of outer margin black in all the wings, two parallel angulated blackish discal lines, the outer one white-bordered; body below white: expanse of wings 11 lines.

Ayrão, Rio Negro, 3rd July, 1874.

A single specimen was taken at light during rain.

\section{Apphadana, Walker.}

119. Apphadana liturata.

Apphadana liturata, Walker, Lep. Het. Suppl. iii. p. 1094 (1865).

Parentins, 2nd April, 1874.

TRANS. ENT. SOC. 1879.-PART I. (APR.) 
120. Apphadana croceiceps.

Thermesia croceiceps, Walker, Lep. Het. Suppl. iii. p. 1050 (1865).

Rio Jutahi, 3rd January, 1875.

Only a single female example: the type is a male.

\section{Dagassa, Walker.}

\section{Dagassa vulgaris, n. sp.}

Allied to D. eupithecioides and "Selenis" digna, Felder; greyish-brown, with darker head and collar; wings suffused with silver-grey, crossed beyond the discoidal cells by an oblique tricoloured line, elbowed towards the costa of primaries, testaceous, with black internal and white external edge; an irregular discal series of whitish-edged black spots, the three last (near anal angle of secondaries) large and close together; a subconfluent marginal series of black linear spots; fringe pale testaceous, intersected by two slender parallel central brown lines and with brown external edge; primaries with a black-edged $>$-shaped white marking at the end of the cell; an irregular black line across the cell; costa beyond the middle black, dotted with white; secondaries with a black spot at the end of the cell; undersurface cinereous, body very pale; markings of the wings nearly as above, but the postmedian line dentate-sinuate, black, with pale external edge; discal black spots confined to the primaries; black line across the cell, only represented by the orbicular spot, which is black and punctiform; costa not black, but dotted beyond the middle with whitish : expanse of wings 11 lines.

São Antonio, Rio Negro, 5th July; Mamiva, Rio Purus, 28th September; Sepatiny, 29th September; Aruma, 4th October; Pariti, 5th October; Gavião, Rio Juruá, 10th November, 1874.

\section{Dagassa juruana, n. sp.}

Pale testaceous with a faint rosy tinge ; a nearlystraight fulvous line, margined on both sides by black lines and bordered internally with whitish across both wings just beyond the middle; external area suffused (excepting a patch at apex and a second at external angle of primaries and the border of secondaries) with dark greyish-brown; an irregular discal series of pale-edged hastate black spots; a marginal series of depressed trian- 
gular black spots; fringe intersected by a grey line; primaries with two or three black basal dots; an irregular black line across the cell; reniform outlined in black, with black centre; secondaries with annular black discocellular spot; undersurface pale sordid sandy-brownish; markings dusky, ill-defined: expanse of wings 11 lines.

Rio Juruá, 12th November, 1874.

Only a single example obtained.

The genus Dagassa chiefly differs from Apphadana in its longer and more slender palpi. "Homoptera" diminutiva of Walker may be added to the genus.

The type of Blanona (B. selenisoides) is Menecina bifacies.

The genera Mareura and Daxata should be placed near Mulelocha.

\section{Selenis, Guénée.}

123. Selenis sueroides.

Selenis sueroides, Guénée, Noct. iii. p. 362, n. 1838 (1852).

Ilha Cuxinara, Rio Solimões, 13th October; Rio Juruá, 13th November, 1874.

\section{Renodes, Guénée.}

124. Renodes (?) modesta, n. sp.

Pale sandy-brown, greyish in certain lights, finely irrorated with black; wings with a slender undulated blackish marginal line uniting a marginal series of black spots; a postmedian oblique fulvous stripe, black-edged internally, diffused externally; an ill-defined whitish stripe just within the black edge; outer border sordid, limited internally by a sinuous dusky line; primaries with the discoidal spots small and white, the reniform being semi-transparent; a falciform blackish line across the basal area; a blackish costal dash just beyond the cell; undersurface sandywhitish; primaries suffused with greyish in the centre; reniform white spot as above; margin of all the wings as above; palpi dusky: expanse of wings 1 inch $2-3$ lines.

Sepatiny, Rio Purus, 29th September, 1874; Boaventura, Rio Jutahi, 26th January, 1875.

The primaries are rather more angular than in the only figured species of this genus, but the other characters seem to agree. 


\section{Capnodes, Guénée.}

125. Capnodes sterope.

Phalcena (Noctua) sterope, Cramer, Pap. Exot. iv. p. 40, pl. 302, fig. E (1782).

Capnodes obliterata, Walker, Lep. Het. xv.p. 1600, n. 1 (1858).

Capnodes sufficiens and "Thermesia" prospera are allied species; the latter is clearly very similar to C. anhypa, although distinct.

Aramia, Rio Purus, 4th October, 1874.

126. Capnodes imitans.

Capnodes imitans, Walker, Lep. Het. xv. p. 1606, n. 17 (1858).

Capnodes exhilarans, Walker, 1. c. p. 1609, n. 22 (1858).

Capnodes uncinata? Felder, Reise der Nov. Lep. iv. pl. 119, fig. 10 (1875).

Rio Mauhes, $5^{\circ} 30^{\prime}$ S., 29 th April, 1874.

If Felder's insect is distinct, it is one of the most closelyallied species in existence; but I think there can be little doubt that it is a very slight variety of $C$. imitans.

127. Capnodes pallida, n. sp.

Whity-brown; wings covered with short fine black striations; an ill-defined curved discal series of black dots; a marginal series of black dots; primaries with a brickred spot surrounded by a squamose black zone at base of inferior discoidal interspace; outer border irregularly greyish, dusky opposite to the end of the cell; secondaries with a bright brick-red spot, as in primaries; outer border irregularly greyish; primaries below smoky-grey, reticulated with blackish; an ill-defined discal series of black dots; fringe whitish; secondaries greyish-white, reticulated with blackish; discocellulars black; a dusky transverse postmedian streak, and an interrupted submarginal streak; outer border narrowly dusky; body sordid white: expanse of wings 1 inch 4 lines.

Boa Vista, Rio Jutahi, 1st February, 1875.

More nearly allied to the preceding than to any other species. 
128. Capnodes orbiculata.

Capnodes orbiculata, Felder, Reise der Nov. Lep. iv. pl. 118, fig. 14 (1875).

Boa Vista, Rio Purus, 12th September, 1874.

129. Capnodes sobria.

Thermesia sobria, Walker, Lep. Het. Suppl. iii. p. $1044(1865)$.

Rio Juruá, 3rd November, 1874.

This species is allied to C. obvertens and C. lineus, but the latter appears to be nearer to $C$. irene in its black subapical costal patch.

\section{E130. Capnodes senilis, n. sp.}

Silver-grey; an irregular band, composed of two nearly parallel crinkled chocolate-brown lines, just beyond the middle; discoidal spots outlined in chocolate; a discal series of triangular black dots, followed by a zigzag chocolate line; a nearly marginal series of black dots, united by a dusky zigzag line; primaries crossed near the base by an irregular blackish line; undersurface very pale, discoidal spots black, punctiform; primaries silvery-brown, several costal white dots beyond the middle; a marginal series of black dots; secondaries white with central grey crinkled line and broad grey border; marginal dots as in primaries: expanse of wings 11 lines.

Rio Jutahi, 5th February, 1875.

\section{Capnodes indigna, n. sp.}

Pale earthy-grey, with a very feeble lilacine tint; wings crossed in the centre by a slightly oblique wavy pale line dividing the discocellular spot (on each wing), which is large and ferruginous, with interrupted darker edge; a marginal series of black dots; primaries with a ferruginous spot at base of costa; an irregular ferruginous band, intersected by a wavy pale line, across the basal third; a ferruginous costal spot, divided by the central line, above the reniform or discocellular spot; a small subapical quadrate ferruginous costal spot; costal margin white-dotted beyond the middle; secondaries with a large black spot in the cell, touching the discocellular spot; faint traces of two blackish zigzag discal lines, the inner one of which becomes sharply defined as an oblique black line across the abdominal border; palpi white internally, tarsi above 
black, with white terminations to the joints; undersurface without ferruginous markings or pale lines; discocellular spots indicated by two parallel black lunules; body below whitish: expanse of wings 11 lines.

Sepatiny, Rio Purus, 29th September, 1874.

Capnodes indigna somewhat resembles Bleptina pithosalis, Wlk. (= Megatomis ferritunalis, Wlk.), and the closely-allied $B$. spurcatais of the same author; these two species would be, in my opinion, better placed near Epizeuxis lituralis.

132. Capnodes bistriata, n. sp.

Pale chocolate-brown, vividly shot with violaceous; a marginal series of whitish-edged subconfluent semicircular black spots; an irregular discal series of pale-bordered confluent olivaceous spots; two irregular yellow-edged olivaceous lines, the inner one confined to primaries, the outer one angulated on these wings towards the costa; discoidal spots yellow, with olivaceous borders; palpi whitish; undersurface sordid-white, wings shot with bronzy-cupreous; borders rather broadly grey; discocellulars outlined in grey; primaries greyish; costa beyond the cell white-dotted; secondaries crossed by a central grey line: expanse of wings 11 lines.

Rio Negro, 17th June; Rio Juruá, 13th November, 1874; Boa Vista, Rio Jutahi, lst February, 1875.

Seems allied to $C$. pyralicolor, but smaller, and darker above.

\section{Capnodes lacteigera, n. sp.}

Brown, densely mottled with dark-grey and shot with lilacine; wings with rather pale fringe and margin; a marginal series of depressed subtriangular black dots; a zigzag discal series of blackish spots; a slightly-irregular fulvous postmedian stripe, commencing near costa of primaries as the continuation of an oblique milk-white dash, limited internally, throughout its entire length, by a series of short black-curved virgulæ and dots; discoidal spots slightly tinted with fulvous, with black margins, the "reniform" 3-shaped; an irregular black-edged and partly fulvous-bordered milk-white band across the basal third of primaries; palpi greyish-brown; wings below with black marginal dots; primaries greyish-brown, with cupreous reflections; discoidal spots small and black; two 
curved parallel greyish discal lines; base whitish; secondaries sordid-whitish, with cupreous reflections; a black discocellular spot; a curved discal line and the outer border greyish-brown; a submarginal dusky stripe limiting the border; body creamy-white: expanse of wings 1 inch 1 line.

Near Xibaru, Rio Negro, 25th June, 1874.

Apparently allied to Phalcena striataria of Cramer, wrongly referred, by M. Guénée, to Palindia.

134. Capnodes mundicola.

Capnodes mundicola, Walker, Lep. Het. Suppl. iii. p. 1075 (1865).

Fuliginous-brown; wings crossed by two black-edged flesh-coloured lines, zigzag towards costa of primaries; discoidal spots small and black; a black-edged zigzag pinky-whitish marginal line, and a submarginal series of black-edged spots of the same colour; a dusky transverse line between the two flesh-coloured lines, externally (and especially upon the secondaries) edged with whitish; outer border irregularly pale; abdomen whitish at base; undersurface paler, the outer borders very pale, limited internally by a dusky band; a central dusky line; discocellular dusky: expanse of wings 1 inch 4 lines.

f. Obydos, 8th March; $\uparrow$. Mouth of Parana mirina de Uraria, 5th June, 1874.

Only a single pair obtained; the male is rather darker than the female: $C$. linula seems to be allied to this species, which (excepting in its broader primaries and less strongly-pectinated antennæ) greatly resembles the genus Bithiasa. Walker's description is so incomplete that I have had some difficulty in identifying this species.

\section{Subgenus* Arugisa, Walker.}

135. Capnodes turbata, n. sp.

Primaries slaty-grey, with a faint violaceous shot; a curved and almost semicircular broad belt (covering the

* I disapprove of making subgenera, but when made I prefer to adopt rather than ignore them. Amigisa is structurally like Capnodes, but differs somewhat in coloration. 
basal two-fifths with the exception of the costal border), a quadrate patch immediately beyond the reniform spot, an apical spot, a submarginal lunulated line, and the edges of the marginal black dots, tawny; four parallel zigzag oblique grey lines in pairs; a sigmoidal black line beyond the middle; secondaries tawny with greyish subcostal area; two parallel triangulated central blackish lines; a dusky angular subbasal line; two parallel submarginal greyish lines; palpi slaty-grey; collar dark fulvous; thorax fulvous; abdomen grey; undersurface creamy-white; pectus and undersurface of legs snow-white; tarsi above black with white edges to the joints; primaries with greyish fuliginous costal border and external half, the latter limited internally and crossed by two parallel dusky stripes; marginal black dots as above; secondaries with a minute blackish discocellular annulus; a dusky line beyond the middle, a dusky submarginal streak; outer border greyishfuliginous; marginal black dots as above: expanse of wings 1 inch 1 line.

Rio Jutahi, 5th February, 1875.

Only a single example.

C. subrutilans, C. consocia and C. finipalpis belong to this section of the genus.

\section{Gerisa, Walker.}

136. Gerisa anyx.

Capnodes anyx, Guénée, Noct. iii. p. 378, n. 1866 (1852).

Capnodes rufinans, Walker (nec Guénée), Lep. Het. xv. p. 1603, n. 7 (1858).

Guajaratuba, Rio Purus, 11th September; Rio Juruá, 26th October; Gavião, Rio Juruá, 10th and 12th November ; Tunantins, 23rd November, 1874.

If I have rightly identified this species, Guénée's type must have been a female (not a male); the male is quite unlike that sex of the nearly-allied $G$. rufinans ( $8 G$. discerpt $a=q$ Thermesia torrida, Wlk.), being dissimilar in form from the female, the primaries much rounded with very convex inner margin, the discal line terminating on this margin in a conspicuous white spot, the antennæ very strongly pectinated.

$G$. anyx seems allied to "Capnodes" subguttata of Felder. 
Of other species placed under Capnodes the following may be removed or sunk as synonymes:-

Capnodes melanea is probably a female Pangrapta, $C$. sexplagiata is Phalcena pueritia of Cramer and belongs to Capnodes; C. rotundifera is a Gerisa.

\section{Paranympha, Cramer.}

Chiefly differs from Capnodes in its more solid and compact appearance, the primaries with longer and straighter costal margin and more acute apex. Type, Phalcna (Paranympha) toxea, Cramer.

137. Paranympha albocostata, n. sp.

Clay-coloured, wings crossed by an irregularly-arched white-dotted dusky line; a submarginal series of small black spots and a marginal series of black dots; primaries with snow-white costal edge; a transverse dusky stripe crossing the wing nearly at the end of the cell; a minute black dot enclosed in an ill-defined dusky 3-shaped character at the end of the cell; secondaries with a circular purplish spot speckled with blue at the end of the cell; head dark brown; anterior edge of collar dark brown, followed by a white transverse stripe; wings below sandyochraceous with black discoidal spots, a dusky discal streak; submarginal black spots and marginal dots as above; body below whitish, legs and palpi variegated with ochraceous, ferruginous, black and white: expanse of wings 1 inch 6 lines.

Boaventura, Rio Jutahi, 24th January, 1875.

Only a single specimen was obtained.

\section{Hypenaria, Guénée.}

Wrongly spelt Hypernaria in all Walker's descriptions \& before noting Dr. Trail's captures I shall have to point out some of this author's mistakes:-

H. ortilia, orphna, tarchon and subvelata may be referred to Argidia, H. patula is Latebraria contacta, H. sublineata is an Amphigonia, H. continuens is Azeta uncas, and $H$. punctulosa is a small Lacera; H. interponens is probably $H$. roseispila. 
138. Hypenaria pyrochila, n. sp.

Red-brown washed with lilacine, particularly towards the costa and base of primaries; wings crossed before the middle by an irregularly dentate-sinuate brown line, and beyond the middle by an oblique white-edged brown line, interrupted by scarlet dots upon the veins, retracted (and oblique dentate-sinuate above the elbow) towards costa of primaries; a pale zigzag submarginal line, dotted internally with white; a marginal pink-bordered crinkled black line; extreme margin and base of fringe scarlet; fringe externally dark brown; primaries with an irregularly-undulated brown line towards the base, and between it and the second line the black-edged pale greenishwhite orbicular spot; reniform confluent with a trifid patch separated by the median veins, limited by an undulated blackish line; the lower portion of the reniform part pale greenish, the portion divided by the median veins sandy-yellow; secondaries with a subgeminate ovoid cream-coloured spot at the end of the cell; head and thorax greyish; wings below ochraceous, washed (excepting at base) with reddish, crossed from just before the middle by three curved grey lines, the centre one darkest; discoidal spots small and blackish; body ochraceous, external surfaces of palpi and legs more or less scarlet: expanse of wings 1 inch 9 lines.

Rio Juruá, 7th November, 1874.

Seems allied to $H$. leucospila, chlorospila and angusta.

I have three times gone through the whole of Cramer's plates and indices, but have failed to find any species described or figured by him under the name of $H$. binocula. M. Guénée, however, declares that he describes the species from the figure; therefore, if we adopt Walker's view and call Guénée the author, we have no alternative but to suppose that he described a mirage.

139. Hypenaria triocellata, n. sp.

Allied to the preceding, but the markings less defined, excepting the trifid continuation to the reniform spot, which is replaced by three unequal increasing black blind ocelli with whitish irides: expanse of wings 1 inch 11 lines.

Mouth of Rio Jutahi, 18th January; Santarem, 4th February, 1875. 
Nearly allied to H. rubripalpis, Ctypansa guttiluna, and the scarcely-differing Hypenaria exponens.

\section{Plaxia, Guénée.}

140. Plaxia mormon.

§. Apistis mormon, Felder, Reise der Nov. Lep. iv. pl. 98 , fig. 16 .

Uttary, Rio Purus, 30th September; Uruçaca, Rio Juruá, 9th November; Rio Juruá, near the mouth, 14th November, 1874.

The female is more uniform in tint and paler than the male, its abdomen also is not red: the species is allied to P. macarea.

\section{Plaxia maculigera, n. sp.}

Allied to the preceding; fuliginous-brown, striolated with black and irrorated with pale lilac; a black-edged oblique lilac line beyond the middle from near the abdominal margin of secondaries to near the apex of primaries, the disc immediately beyond this line washed with lilac; traces of a sinuated " extrabasilar" brown line; primaries, with a nearly-circular unequally-bifid bright orange spot, cut by the second median branch; costal margin ochraceous; secondaries with an angular series of black dots on the disc; antennæ, crest and margins of collar pale brown; termination of abdomen and sides of terminal segments ochraceous; tarsi and venter sandy-yellowish ; wings below uniform sericeous greyish-brown, having almost a greasy appearance, striolated with darker brown and crossed by two parallel dark-grey lines; primaries with ochreous costa: expanse of wings 2 inches 2 lines.

§. Serpa, 13th February, 1875.

This species agrees in coloration with "Thermesia" scalena of Felder.

Felder's "Thermesia" (?) infumata, which is evidently a slight variety of Walker's "Hypernaria" anisospila, seems to me to agree with Hübner's Apistis (the type of which is A.fellearis); Plaxia subducta and P. spiloleuca of Walker may also be placed in the same genus; they are closely allied to $H$. anisospila; Hypenaria metastigma is evidently Hübner's A. fellearis. I will not attempt to decide whether Hypenaria and Apistis are sufficiently 
distinct to be regarded as different genera until I have to re-arrange the whole of the Noctuites, and can form a correct estimate as to what characters are sufficient in this tribe to constitute a generic distinction.

\section{Empelathra, Walker.}

To this genus I propose provisionally to refer Orthogramma vacillans = Plaxia ingenua and the following species allied to it.

142. Empelathra scalena.

Thermesia scalena, Felder, Reise der Nov. Lep. iv. pl. 118, fig. 13 .

Lake Cararaucu, 17th April; Marapatá, Rio Negro, 30th December, 1874.

E. scalena differs from E. vacillans exactly as Plaxia maculigera does from $P$. macarea.

143. Empelathra amplificans.

Empelathra amplificans, Walker, Lep. Het. xv. p. 1633, n. 1 (1858).

Paricatuba, 17th October, 1874.

This is a rare species in which the apex of primaries is obliquely truncated, the costal margin is shorter than in the other two species which I have referred to the genus. 


\section{$2 \mathrm{BHL}$ Biodiversity Heritage Library}

1879. "IV. On the Lepidoptera of the Amazons, collected by Dr. James W. H. Trail, during the years 1873 to 1875. By Arthur Gardiner Butler, F.L.S., F.Z.S., \&." Transactions of the Entomological Society of London 27, 19-76. https://doi.org/10.1111/j.1365-2311.1879.tb01978.x.

View This Item Online: https://www.biodiversitylibrary.org/item/48188

DOI: https://doi.org/10.1111/j.1365-2311.1879.tb01978.x

Permalink: https://www.biodiversitylibrary.org/partpdf/35683

\section{Holding Institution}

Smithsonian Libraries

\section{Sponsored by}

Smithsonian

\section{Copyright \& Reuse}

Copyright Status: Public domain. The BHL considers that this work is no longer under copyright protection.

This document was created from content at the Biodiversity Heritage Library, the world's largest open access digital library for biodiversity literature and archives. Visit BHL at https://www.biodiversitylibrary.org. 